Provided for non-commercial research and education use. Not for reproduction, distribution or commercial use.

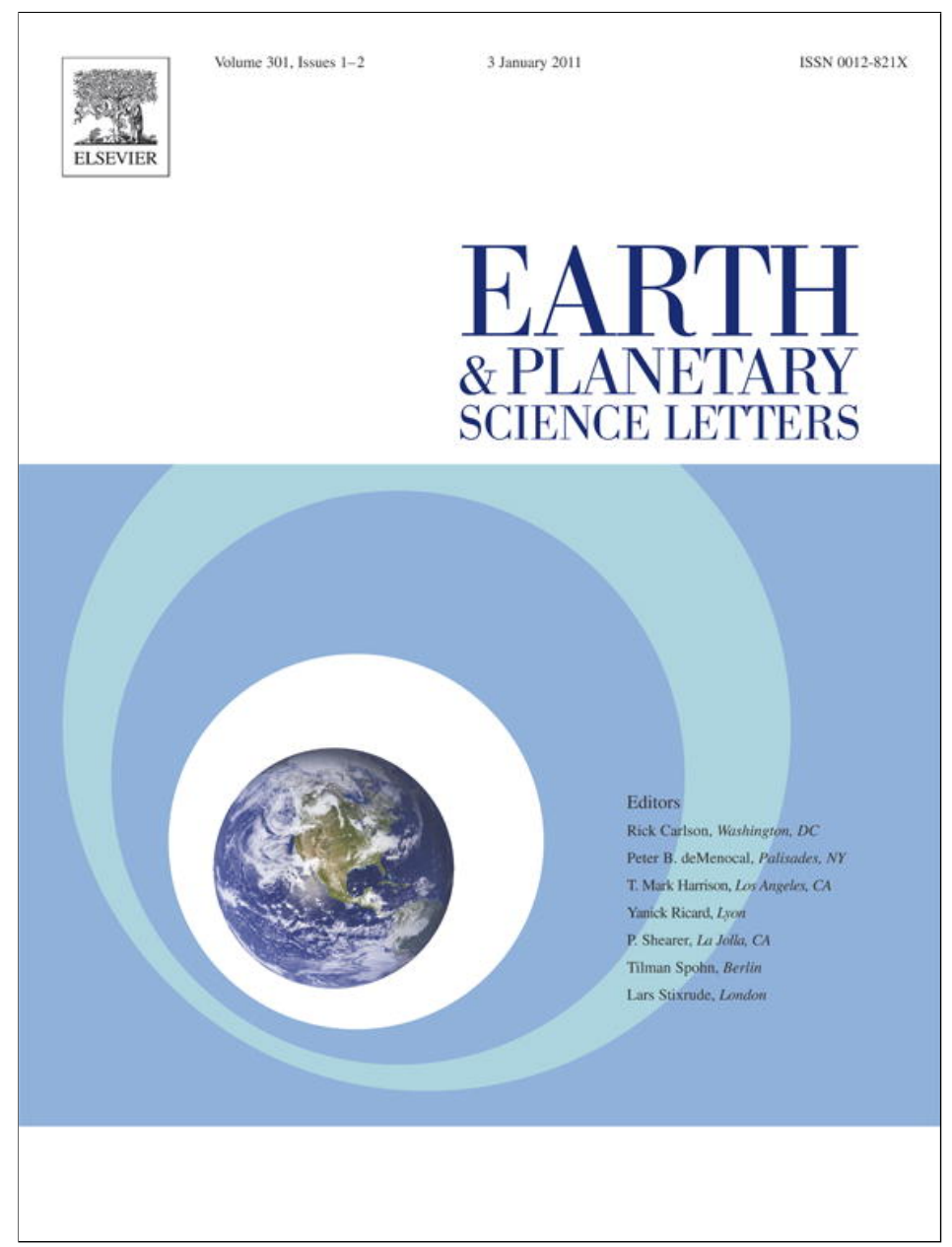

(This is a sample cover image for this issue. The actual cover is not yet available at this time.)

This article appeared in a journal published by Elsevier. The attached copy is furnished to the author for internal non-commercial research and education use, including for instruction at the authors institution and sharing with colleagues.

Other uses, including reproduction and distribution, or selling or licensing copies, or posting to personal, institutional or third party websites are prohibited.

In most cases authors are permitted to post their version of the article (e.g. in Word or Tex form) to their personal website or institutional repository. Authors requiring further information regarding Elsevier's archiving and manuscript policies are encouraged to visit:

http://www.elsevier.com/copyright 


\title{
Greater supply of Patagonian-sourced detritus and transport by the ACC to the Atlantic sector of the Southern Ocean during the last glacial period
}

\author{
Taryn L. Noble ${ }^{\mathrm{a}, *, 1}$, Alexander M. Piotrowski ${ }^{\mathrm{a}}$, Laura F. Robinson ${ }^{\mathrm{b}, 2}$, Jerry F. McManus ${ }^{\mathrm{c}}$, \\ Claus-Dieter Hillenbrand ${ }^{\mathrm{d}}$, Aloys J.-M. Bory ${ }^{\mathrm{e},{ }^{ }}$ \\ a Department of Earth Sciences, University of Cambridge, Downing Street, Cambridge, UK CB2 3EQ \\ b Department of Marine Chemistry and Geochemistry, Woods Hole Oceanographic Institution, Woods Hole, MA 02543, USA \\ ' Department of Earth and Environmental Science, Columbia University, Lamont-Doherty Earth Observatory, Comer Bldg. Room 239, P.O. Box 1000, 61 Route 9W, Palisades, \\ NY 10964-8000, USA \\ ${ }^{d}$ British Antarctic Survey, High Cross, Madingley Road, Cambridge, UK CB3 OET \\ e Lamont-Doherty Earth Observatory of Columbia University, NY 10964, USA
}

\section{A R T I C L E I N F O}

\section{Article history:}

Received 31 March 2011

Received in revised form 10 September 2011

Accepted 4 October 2011

Available online xxxx

Editor: P. DeMenocal

\section{Keywords:}

radiogenic isotopes

detritus

flux

provenance

Patagonia

Southern Ocean

\begin{abstract}
A B S T R A C T
Reconstructing past detrital flux and provenance in the Southern Ocean provides information about changes in source regions associated with climate variations and transport pathways. We present a Last Glacial Maximum (LGM) to Holocene comparison of ${ }^{230} \mathrm{Th}$ normalised fluxes combined with sediment provenance data ( $\mathrm{Pb}, \mathrm{Nd}$ and $\mathrm{Sr}$ isotopes) from a latitudinal core transect in the eastern Atlantic sector of the Southern Ocean (ODP Leg 177 cores). We compare the radiogenic isotopic composition (IC) of detritus in these cores to that of cores proximal to potential source areas.

We observe a well-defined latitudinal Holocene gradient in both detrital flux and provenance of sediment. High detrital fluxes in the north are associated with terrigenous material derived from southern Africa, while low detrital fluxes in the south are associated with supply from southern South America, West Antarctica and the South Sandwich Islands. The data suggest that this well-defined Holocene gradient in detrital flux and sediment provenance is controlled by the flow of the Antarctic Circumpolar Current (ACC) and the position of its frontal zones. The LGM is characterised by 2 to 6 times higher than modern detrital fluxes at most ODP Leg 177 sites. The LGM detrital fluxes do not show a latitudinal trend and suggest a greater supply of glaciogenic detritus sourced from southern South America. Glacial Patagonian outwash sediments $(<5 \mu \mathrm{m}$ fraction) were analysed and compared to the bulk compositions of the marine sediments. The $\mathrm{Pb}$ IC of the Patagonian sediments is very similar to the glacial IC of sediments in the Scotia Sea and at $\sim 49^{\circ} \mathrm{S}$ latitude in the eastern Atlantic sector. We propose that the glacial IC of sediments is controlled by increased delivery of Patagonian detritus initially supplied by glaciers and then transported at depth via the ACC.
\end{abstract}

(c) 2011 Elsevier B.V. All rights reserved.

\section{Introduction}

The element iron, an essential micronutrient, is added to the global ocean by the dissolution of silicate detritus. The input of detrital sediment into the Southern Ocean is particularly important because it is a High Nutrient Low Chlorophyll (HNLC) region. Martin (1990) suggested that enhanced dust supply to the sub-Antarctic Southern Ocean during the LGM might have stimulated the biological pump, transferring

\footnotetext{
* Corresponding author.

E-mail address: Taryn.Noble@utas.edu.au (T.L. Noble).

1 Present address: University of Tasmania, School of Earth Sciences, Private Bag 79 Hobart, Tasmania, 7001, Australia.

2 Present address: University of Bristol, Department of Earth Sciences, Wills Memorial Building, Queens Road, Bristol, BS8 1RJ, UK.

${ }^{3}$ Present address: GEOSYSTEMES, Université des Sciences et Technologies de Lille, 59655 Villeneuve d'Ascq Cedex, France.
}

carbon to the deep ocean and potentially contributing to the low atmospheric $\mathrm{CO}_{2}$ concentrations ( Fe fertilisation hypothesis). Ice core studies from East Antarctica have established that during the LGM, the dust flux to Antarctica was $\leq 25$ times higher than during interglacial periods (Lambert et al., 2008; Petit et al., 1999). However, there has thus far been no direct evidence for a significant contribution of Patagonian dust to the detrital fraction recorded in marine sediments of the Atlantic sector of the Southern Ocean (Diekmann et al., 2000; Walter et al., 2000).

Identifying sources and fluxes of terrigenous detritus to the ocean provides a means of reconstructing past sediment input and transport mechanisms (e.g. Prospero et al., 2002), allowing reconstruction of past changes in dust plumes (Grousset et al., 1998) and ocean currents (Diekmann et al., 2000; Franzese et al., 2006). Potential source areas of detrital sediments in the Atlantic sector of the Southern Ocean include southern South America, islands of the Scotia Arc, West Antarctica (including the Antarctic Peninsula), East Antarctica 
and southern Africa. Terrigenous detritus can be delivered to the Atlantic sector of the Southern Ocean via aeolian transport from arid regions, such as Patagonia and southern Africa (e.g. Grousset et al., 1992), and current transport mainly by the ACC, but also the Weddell Gyre and the Agulhas Current (e.g. Diekmann et al., 2000, 2003; Kuhn and Diekmann, 2002; Latimer et al., 2006). Since a thick ice sheet covers the surface of the Antarctic continent, ice rafting is the dominant transport mechanism for input from this source. Ice rafted debris (IRD), however, constitutes only a minor proportion of the detrital fraction of marine sediments in the pelagic Southern Ocean (e.g. Diekmann et al., 2003; Teitler et al., 2010).

Isotope studies have established Patagonia as the most important glacial source region of dust to Antarctica (Grousset et al., 1992: Basile et al., 1997; Delmonte et al., 2004, 2010) and model results indicate that there were probably significant Patagonian dust inputs to the Southern Ocean during the LGM (Li et al., 2008). Patagonia is the only continental landmass south of $39^{\circ} \mathrm{S}$ with an arid climate and low precipitation rates, where strong westerly winds dominate (Prospero et al., 2002). Glacial-interglacial fluctuations of Patagonian glaciers likely controlled the availability of fine sediment (Sugden et al., 2009). During the LGM, extensive outwash plains and fluvial systems distributed vast amounts of sediment from the Andes across the plains of Patagonia, providing a major source of dust. Combined with a reduced hydrological cycle during the LGM the lifetime of particles in the atmosphere and their travel distances increased (Lambert et al., 2008). A lower LGM sea level allowed glaciers to advance far onto continental shelf resulting in high inputs of glaciogenic detritus from the Patagonian shelf directly into the Southern Ocean (Diekmann et al., 2000; Marinoni et al., 2008).

In this study we combine the use of $\mathrm{Pb}, \mathrm{Nd}$ and $\mathrm{Sr}$ isotopes to constrain sediment sourcing with detrital flux estimates using ${ }^{230} \mathrm{Th}$-normalisation. The five cores chosen for these analyses were recovered during Ocean Drilling Program (ODP) Leg 177 and extend across the frontal system of the ACC, located between the Subtropical (STF) and Subantarctic (SAF) Fronts (Sites 1088, 1089,1090) and between the PF and the Southern Boundary of the ACC (SBACC) (Sites 1093 and 1094) in the circum-Antarctic opal belt (Fig. 1). The SAF and PF separate warm, nutrient-poor surface waters in the north from cold, nutrient-rich surface waters in the south. The zonal character of the surface ACC is also reflected in sediments on the seafloor. Sediments bearing calcareous microfossils and enriched in the clay mineral kaolinite prevail north of the PF, while sediments bearing siliceous microfossils and enriched in the clay mineral chlorite dominate to the south. (e.g. Diekmann, 2007; Diekmann et al., 2003). Thus the ODP Leg 177 cores provide an excellent location to monitor changes in environmental conditions relating to sediment sources and transport mechanisms to the eastern Atlantic sector of the Southern Ocean.

\section{Material and methods}

To reconstruct the sources of terrigenous detritus supplied to the Leg 177 transect and examine past variability in sediment provenance, we have measured the glacial and Holocene $\mathrm{Pb}, \mathrm{Nd}$ and $\mathrm{Sr}$ isotope ratios of bulk sediment in cores proximal to potential source regions (Fig. 1, Table 1). We have defined the potential sources using cores located on the eastern Antarctic Peninsula margin in the northwestern Weddell Sea (KC088, KC089, GC027); northern (TPC290) and southern Scotia Sea (TPC288); and from the East Antarctic continental slope in the southern Weddell Sea (PS2819 and PS2820) (Table 1). Provenance of detritus originating from southern Africa and transported by the Agulhas Current to the northerly Leg 177 sites is constrained by data from core WIND 1B. We also studied $\mathrm{Pb}$ isotopes in late-glacial lake sediment samples from Patagonia ( $<5 \mu \mathrm{m}$ fraction), whose $\mathrm{Nd}$ and $\mathrm{Sr}$ isotopes were analysed by Sugden et al. (2009).

Detrital fluxes were measured on bulk sediments from the ODP Leg 177 cores using ${ }^{230} \mathrm{Th}$ normalisation. Accurate estimates of the vertical flux of detrital sediment to the seafloor are vital for reconstructing past climates. The isotope ${ }^{232} \mathrm{Th}$ is used to trace the input of silicate detritus to the ocean because it is sourced only from terrestrial inputs. The ${ }^{230} \mathrm{Th}$ normalisation method (Bacon, 1984; Francois et al., 2004) is based on the assumption that the known production rate of ${ }^{230} \mathrm{Th}$ in the water column from the decay of ${ }^{234} \mathrm{U}$ dissolved in seawater is equal to ${ }^{230} \mathrm{Th}$ scavenged to the sediment particles

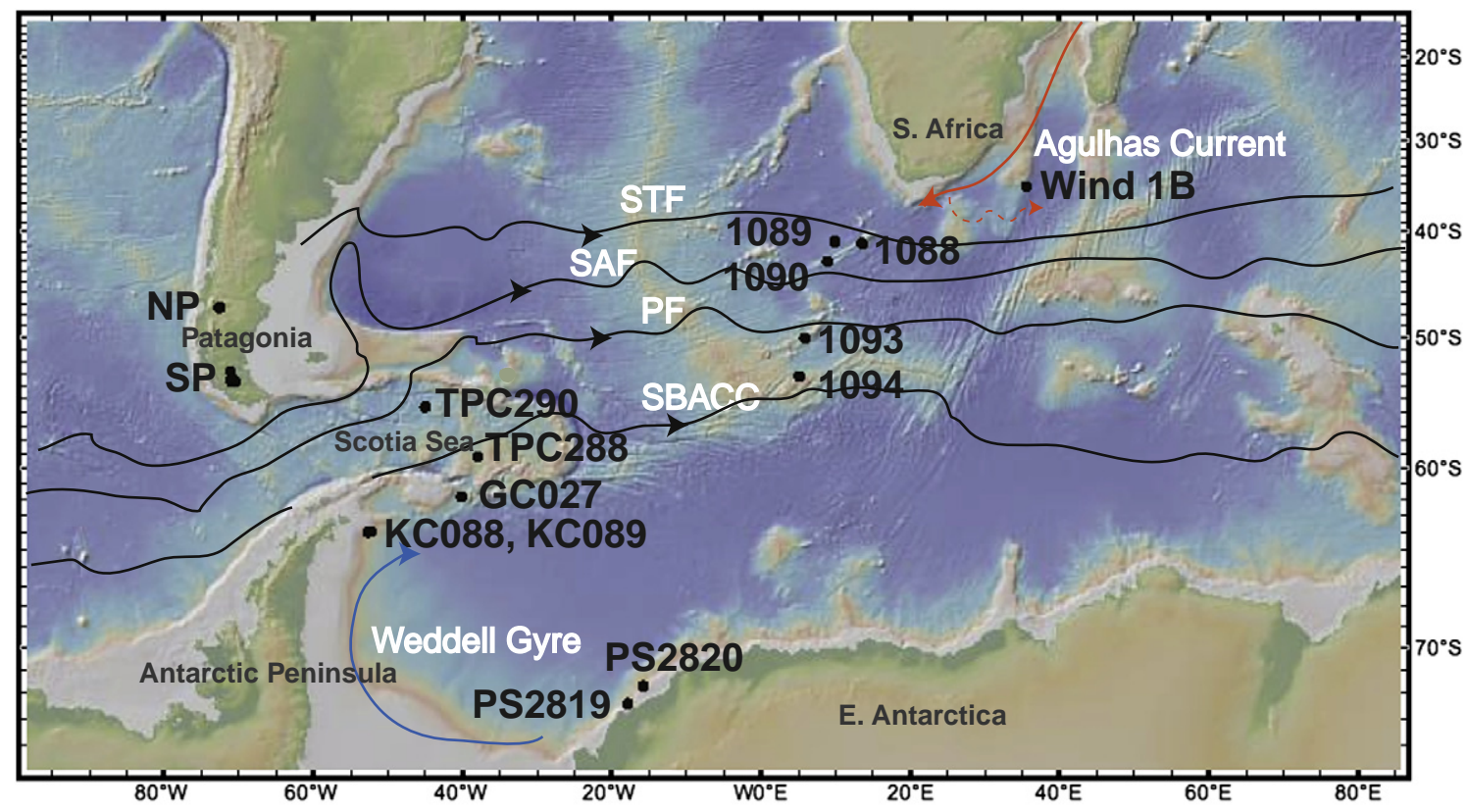

Fig. 1. Map of the study area with locations of samples analysed in this study (http://www.geomapapp.org). The main surface currents are shown by the fronts of the Antarctic Circumpolar Current (ACC), the Weddell Gyre and the Agulhas Current. STF: Subtropical Front, SAF: Subantarctic Front, PF: Polar Front, SBACC: Southern Boundary of the Antarctic Circumpolar Current [ACC] Front, NP: Northern Patagonia, SP: Southern Patagonia. 
Table 1

Location and depth of marine sediment cores.

\begin{tabular}{lllll}
\hline Location & Core & Latitude & Longitude & $\begin{array}{l}\text { Depth } \\
(\mathrm{m})\end{array}$ \\
\hline Agulhas Ridge & ODP177-1088 & $41^{\circ} 8^{\prime} 2^{\prime \prime} \mathrm{S}$ & $13^{\circ} 33^{\prime} 8^{\prime \prime} \mathrm{E}$ & 2082 \\
Cape Basin & ODP177-1089 & $40^{\circ} 56^{\prime} 2^{\prime \prime} \mathrm{S}$ & $9^{\circ} 53^{\prime} 6^{\prime \prime} \mathrm{E}$ & 4620 \\
Agulhas Ridge & ODP177-1090 & $42^{\circ} 54^{\prime} 8^{\prime \prime} \mathrm{S}$ & $8^{\circ} 54^{\prime} \mathrm{E}$ & 3702 \\
Near Polar Front & ODP177-1093 & $49^{\circ} 58^{\prime} 6^{\prime \prime} \mathrm{S}$ & $5^{\circ} 51^{\prime} 9^{\prime \prime} \mathrm{E}$ & 3626 \\
South of SBACC & ODP177-1094 & $53^{\circ} 10^{\prime} 8^{\prime \prime} \mathrm{S}$ & $5^{\circ} 7^{\prime} 8^{\prime \prime} \mathrm{E}$ & 2807 \\
SW Indian Ocean & WIND1B & $35^{\circ} 07^{\prime} 31^{\prime \prime} \mathrm{S}$ & $35^{\circ} 32^{\prime} 12^{\prime \prime} \mathrm{E}$ & 4156 \\
N Weddell Sea & GC027 & $61^{\circ} 46^{\prime} 48^{\prime \prime} \mathrm{S}$ & $40^{\circ} 7^{\prime} 48^{\prime \prime} \mathrm{W}$ & 3470 \\
N Weddell Sea & KC088 & $63^{\circ} 57^{\prime} 0^{\prime \prime} \mathrm{S}$ & $52^{\circ} 42^{\prime} 0^{\prime \prime} \mathrm{W}$ & 1441 \\
N Weddell Sea & KC089 & $63^{\circ} 55^{\prime} 12^{\prime \prime} \mathrm{S}$ & $52^{\circ} 19^{\prime} 48^{\prime \prime} \mathrm{W}$ & 1449 \\
S Scotia Sea & TPC288 & $59^{\circ} 8^{\prime} 24^{\prime \prime} \mathrm{S}$ & $37^{\circ} 57^{\prime} 36^{\prime \prime} \mathrm{W}$ & 2864 \\
N Scotia Sea & TPC290 & $55^{\circ} 33^{\prime} 0^{\prime \prime} \mathrm{S}$ & $45^{\circ} 0^{\prime} 36^{\prime \prime} \mathrm{W}$ & 3826 \\
East Antarctic slope & PS2819 & $72^{\circ} 23^{\prime} 24^{\prime \prime} \mathrm{S}$ & $17^{\circ} 51^{\prime} 12^{\prime \prime} \mathrm{W}$ & 1432 \\
East Antarctic slope & PS2820 & $71^{\circ} 40^{\prime} 16^{\prime \prime} \mathrm{S}$ & $15^{\circ} 46^{\prime} 48^{\prime \prime} \mathrm{W}$ & 1341 \\
\hline
\end{tabular}

and buried in the underlying sediments. This assumption appears to hold at least approximately in most of the ocean based on sediment traps, core data and model studies (Henderson et al., 1999; McManus et al., 1998; Hoffmann and McManus, 2007; Yu et al., 2001) and results in the nearly constant burial of excess ${ }^{230} \mathrm{Th}$ in sediment, unsupported by the decay of lattice bound uranium. The highly particle reactive nature of thorium and its short residence time in the water column ( $<4$ years in the upper water column and up to 40 years in the deep water) provide an excellent method to estimate past particle fluxes (e.g. Martinez-Garcia et al., 2009), including bulk and component fluxes, even when detrital fluxes vary over a wide range (McManus et al., 1998; Robinson et al., 2008).

\subsection{Sample selection}

\subsubsection{Age models for the Leg 177 sediment cores}

The age models for the Leg 177 cores were presented in Hodell et al. (2003a,b) and Shipboard Scientific Party (1999). In all cases, the chronologies for these cores were sufficiently constrained to identify LGM and Holocene samples.

\subsubsection{Chronologies of samples used for the identification of potential source regions}

Two samples from WIND 1B (1-2 and $28-29 \mathrm{~cm})$, a box core retrieved on the R/V Charles Darwin Cruise 129 in 2001, were used to characterise detritus delivered by the Agulhas Current. No definitive age model for this core was developed but based on the high sedimentation rates ( 5 to $10 \mathrm{~cm} / \mathrm{ka}$ ) of nearby cores the samples were taken from Holocene sediments (McCave, pers. comm.).

The age models for cores KC088 and KC089 from the NW Weddell Sea were established by AMS ${ }^{14} \mathrm{C}$ dating of calcareous microfossils (Smith et al., 2010). The age model for core GC027, located also in the NW Weddell Sea, is based on diatom and radiolarian biostratigraphy combined with magnetostratigraphy (Jordan and Pudsey, 1992). The age models for cores TPC288 and TPC290 were determined by combining AMS ${ }^{14} \mathrm{C}$ dates on the acid-insoluble organic fraction, radiolarian biostratigraphy, and correlation of the magnetic susceptibility records of the cores with the dust flux record of the EPICA Dome $\mathrm{C}$ ice core (Pugh et al., 2009). The LGM and Holocene in cores from the East Antarctic continental slope (PS2819 and PS2820) were identified by Vernaleken (1999) using the lithostratigraphy developed by Grobe and Mackensen (1992) for this part of the Weddell Sea margin.

Eight samples of the finest fraction $(<5 \mu \mathrm{m})$ of lacustrine clay/silts from Patagonia were used to measure their $\mathrm{Pb}$ isotope composition. These samples are of LGM age according to AMS ${ }^{14} \mathrm{C}$ dating (Sugden et al., 2009).

\subsection{Procedures}

\subsubsection{Provenance tracers $\mathrm{Pb}, \mathrm{Nd}$ and $\mathrm{Sr}$ isotopes}

In order to analyse the detrital silicate fraction of the bulk sediment, authigenic phases were removed. Carbonate and Fe-Mn oxides were removed using buffered acetic acid and $0.02 \mathrm{M}$ hydroxylamine hydrochloride in 25\% (v/v) acetic acid respectively (Chester and Hughes, 1967; Piotrowski et al., 2004; Rutberg et al., 2000). To ensure that all the Fe-Mn oxides were removed, the samples were treated with a further $1 \mathrm{M} \mathrm{HH}$ in $25 \%$ acetic acid for $3 \mathrm{~h}$ at $90{ }^{\circ} \mathrm{C}$ (Bayon et al., 2002). Biogenic silica was not removed from the bulk sediment samples because the concentrations of $\mathrm{Pb}, \mathrm{Nd}$, and $\mathrm{Sr}$ in opal are insignificant relative to their concentrations in the detritus. The $<5 \mu \mathrm{m}$ Patagonian samples were chemically treated by Sugden et al. (2009) to remove carbonates, Fe oxides, amorphous silica and alumina.

Sediment digestions were carried out on the detrital fraction using $\sim 50 \mathrm{mg}$ of bulk sediment. The samples were dissolved using pressure bombs in a standard three-stage treatment of 47\% ROMIL HF, $6 \mathrm{M}$ Quartz Distilled (QD) $\mathrm{HNO}_{3}$, and $6 \mathrm{M} \mathrm{QD} \mathrm{HCl}$, and heated to $180^{\circ} \mathrm{C}$ for at least $8 \mathrm{~h}$. The $\mathrm{Pb}, \mathrm{Nd}$ and $\mathrm{Sr}$ isotopes were separated following the procedures of Hemming and Rasbury (2000), Rutberg et al. (2000) and Bickle et al. (2003).

$\mathrm{Pb}$ and $\mathrm{Nd}$ isotopes were analysed using a Nu Plasma multicollector plasma mass spectrometer (MC-ICP-MS) at the University of Cambridge. For $\mathrm{Pb}$ isotope analysis, the standards and samples were spiked with thallium at a $\mathrm{Pb} / \mathrm{Tl}$ ration of $2: 1$, in order to correct for mass fractionation (Walder and Furuta, 1993). The samples were bracketed with NBS 981, with sufficient wash out time between standard and sample. The samples were analysed in three sessions during which the bracketing standards had an average value and external re-

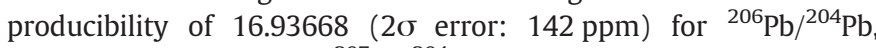
$15.49711(159 \mathrm{ppm})$ for ${ }^{207} \mathrm{~Pb} /{ }^{204} \mathrm{~Pb}$ and 36.71501 (188 ppm) for ${ }^{208} \mathrm{~Pb} /{ }^{204} \mathrm{~Pb}(\mathrm{n}=118)$.

The Nd analyses were performed according to the method of Halliday et al. (1998). During the course of analysis (three sessions) the bracketing standards (JNdi-1; Tanaka et al., 2000) had an average ${ }^{143} \mathrm{Nd} /{ }^{144} \mathrm{Nd}$ ratio of 0.512127 and an external reproducibility of $29 \mathrm{ppm}(\mathrm{n}=92)$, which corresponds to an average $\varepsilon_{\mathrm{Nd}}$ error of \pm 0.30 . For convenience, ${ }^{143} \mathrm{Nd} /{ }^{144} \mathrm{Nd}$ ratios are presented as $\varepsilon_{\mathrm{Nd}}$, the deviation from the chondritic value $\left({ }^{143} \mathrm{Nd} /{ }^{144} \mathrm{Nd}_{(\mathrm{CHUR})}=0.512638\right.$; Jacobsen and Wasserburg, 1980). This deviation is calculated via $\varepsilon_{\mathrm{Nd}}={ }^{143} \mathrm{Nd} /{ }^{144} \mathrm{Nd}_{\text {(measured) }} /\left({ }^{143} \mathrm{Nd} /{ }^{144} \mathrm{Nd}_{(\text {CHUR })}-1\right) \times 10^{4}$.

$\mathrm{Sr}$ isotopes were analysed on the TIMS Sector 54 at the University of Cambridge. The $\mathrm{Sr}$ isotope ratios were measured using a triple collector dynamic algorithm, normalised to a ${ }^{86} \mathrm{Sr} /{ }^{88} \mathrm{Sr}$ ratio of 0.1194 . For each sample 200 ratios were run, in a total of three sessions. The mean standard NBS 987 value for 90 analyses run throughout the duration of the sessions was 0.710266 with a $2 \sigma$ external error of 0.000022 . The ${ }^{88} \mathrm{Sr}$ beam voltages were $\sim 1.5 \mathrm{~V}$. Procedural blanks were insignificant compared to the amounts of $\mathrm{Pb}, \mathrm{Nd}$ and $\mathrm{Sr}$ in the samples.

\subsubsection{Thorium isotopes}

For thorium isotope analysis we used $\sim 50 \mathrm{mg}$ aliquots of ovendried $\left(40^{\circ} \mathrm{C}\right)$ sediment. The bulk sediment digestions were carried out using HF and perchloric acid, as described by McManus et al. (2004) and Pichat et al. (2004). U and Th were separated and purified using anion-exchange column chemistry based on Edwards et al. (1986). Isotopic analyses were made using a Finnigan Element 2 single-collector inductively coupled plasma mass spectrometer at Woods Hole Oceanographic Institution. Regular standards and acid rinses were monitored to account for machine blank, peak tailing, mass bias, counter gain and drift.

The seawater-derived (unsupported or "excess") ${ }^{230}$ Th concentration used to calculate detrital and mass fluxes was corrected for the presence of detrital thorium, the decay of ${ }^{230} \mathrm{Th}$ (half-life 75,000 years), 
and the ingrowth of ${ }^{230} \mathrm{Th}$ from the decay of authigenic ${ }^{234} \mathrm{U}$ (half-life $2.45 \times 10^{5}$ years).

\section{Results}

\subsection{Eastern Atlantic sector transect - Holocene}

There is a well-defined latitudinal gradient during the Holocene for both detrital flux and provenance, as determined by thorium isotopes and radiogenic isotope characteristics, respectively. The highest ${ }^{232}$ Th fluxes are observed in the north, near to southern Africa; and lowest fluxes in the south, closer to Antarctica (Fig. 2, Supp. Table 2). The same trend applies to the bulk detrital fluxes, converted from the ${ }^{232} \mathrm{Th}$ fluxes by assuming that the concentration of ${ }^{232} \mathrm{Th}$ (using an upper crust concentration of 10.7 ppm; Taylor and McLennan, 1985) from all sources is the same. Similarly, the $\mathrm{Pb}, \mathrm{Nd}$ and $\mathrm{Sr}$ isotope distributions show well-defined geochemical gradients across the transect (Fig. 3, Supp. Table 3). Cores in the north have a more cratonic signature characterised by low $\varepsilon_{\mathrm{Nd}}$ and high ${ }^{87} \mathrm{Sr} /{ }^{86} \mathrm{Sr}$ and $\mathrm{Pb}$ isotope ratios compared to cores further south, which are more radiogenic in $\varepsilon_{\mathrm{Nd}}$ and less radiogenic for ${ }^{87} \mathrm{Sr} /{ }^{86} \mathrm{Sr}$ and $\mathrm{Pb}$ isotopes the closer the sites are to the Antarctic.

\subsection{Eastern Atlantic transect - LGM}

In contrast to the Holocene, there is no systematic spatial pattern in detrital fluxes during the LGM. However, an overall increase with the same or higher detrital fluxes at the LGM compared to the Holocene is observed at all four sites (Fig. 2). The most significant LGM to Holocene change is observed south of the PF, with the largest change in ${ }^{232} \mathrm{Th}$ flux at Site $1093\left(69.8 \pm 3.7 \mu \mathrm{g} \mathrm{m}^{-2} \mathrm{yr}^{-1}\right)$, where it is 6 times higher than during the Holocene.

A systematic LGM to Holocene change in $\varepsilon_{\mathrm{Nd}}$ and ${ }^{87} \mathrm{Sr} /{ }^{86} \mathrm{Sr}$ isotopic signature occurs at three of our four core sites (Fig. 3). The glacial values at Sites 1088 and 1089 are all more radiogenic in $\varepsilon_{\mathrm{Nd}}$ and less radiogenic in ${ }^{87} \mathrm{Sr} /{ }^{86} \mathrm{Sr}$ isotope ratios compared to the Holocene. The southernmost Site 1094 deviates from this trend.

\subsection{Isotopic composition of detritus in potential source regions}

\subsubsection{Agulhas Current}

The Holocene $\varepsilon_{\mathrm{Nd}},{ }^{87} \mathrm{Sr} /{ }^{86} \mathrm{Sr}$ and $\mathrm{Pb}$ isotopes measured at site WIND 1B have the least radiogenic $\varepsilon_{\mathrm{Nd}}(-12.8 \pm 0.4)$ and most radiogenic ${ }^{87} \mathrm{Sr} /{ }^{86} \mathrm{Sr}(0.72586 \pm 0.00001)$ and ${ }^{207} \mathrm{~Pb} /{ }^{204} \mathrm{~Pb}(19.14150 \pm$
0.0005) values of all cores analysed, characteristic of cratonicderived sediment from southern Africa (Figs. 5, 6).

\subsubsection{Scotia Sea}

The Scotia Sea cores TPC288 (southern site) and TPC290 (northern site) show similar intermediate $\varepsilon_{\mathrm{Nd}}$ values $\left(\sim-5 \varepsilon_{\mathrm{Nd}}\right)$ during the Holocene. However, TPC288 has higher ${ }^{87} \mathrm{Sr} /{ }^{86} \mathrm{Sr}$ and lower ${ }^{207} \mathrm{~Pb} /{ }^{204} \mathrm{~Pb}$ values compared to TPC290 (see Supp. Table 3). The glacial $\varepsilon_{\mathrm{Nd}}$ isotope composition for TPC288 and TPC290 is similar to Holocene values, with more variability shown in the ${ }^{87} \mathrm{Sr} /{ }^{86} \mathrm{Sr}$ and ${ }^{207} \mathrm{~Pb} /{ }^{204} \mathrm{~Pb}$ ratios.

\subsubsection{Eastern Antarctic Peninsula}

During the Holocene, the three core sites (KC088, KC089 and GC027) from the western Weddell Sea have less radiogenic $\varepsilon_{\mathrm{Nd}}$ values and more radiogenic ${ }^{87} \mathrm{Sr} /{ }^{86} \mathrm{Sr}$ and $\mathrm{Pb}$ isotope ratios than the Scotia Sea cores. During the LGM, the isotope ratios at all sites from the eastern Antarctic Peninsula margin are consistently less radiogenic for $\varepsilon_{\mathrm{Nd}}$ and more radiogenic for ${ }^{87} \mathrm{Sr} /{ }^{86} \mathrm{Sr}$ and $\mathrm{Pb}$ isotope ratios than during the Holocene (Fig. 4).

\subsubsection{East Antarctica}

In the southern Weddell Sea, cores PS2819 and PS2820 show the largest LGM to Holocene shift observed in $\varepsilon_{\mathrm{Nd}}$, with a systematic trend from less radiogenic $(-10)$ to more radiogenic $(-2)$ values, associated with only a small change in ${ }^{87} \mathrm{Sr} /{ }^{86} \mathrm{Sr}$ ratios (Fig. 4). We observe the least radiogenic $\mathrm{Pb}$ isotope values of all cores at sites PS2819 and PS2820 (Supp. Table 3) during both the LGM and the Holocene (Fig. 6).

\subsubsection{Patagonia}

Sugden et al. (2009) have previously published the Nd and Sr isotope ratios on glacial $<5 \mu$ m sediments from Patagonian (Figs. 4,5 ). Despite the difference in grain size, the samples Magellan Straits (i.e. in southern Patagonia) have a similar ${ }^{207} \mathrm{~Pb} /{ }^{204} \mathrm{~Pb}$ isotope composition to that of the bulk sediment from both the northern and southern Scotia Sea cores, and also the glacial bulk sediments from cores 1093 and 1094 in the eastern Atlantic sector (Fig. 6 Supp Table 4). By contrast, the northern Patagonian samples have distinct $\mathrm{Pb}$ isotope ratios compared to the southern Patagonian samples, and exhibit more radiogenic isotope values, probably due to the higher abundance of pre-Cambrian to Cambrian basement rocks with $\mathrm{K}-\mathrm{Ar}$ ages of $549 \pm 20 \mathrm{Ma}$ (Pankhurst et al., 1998 and references within).
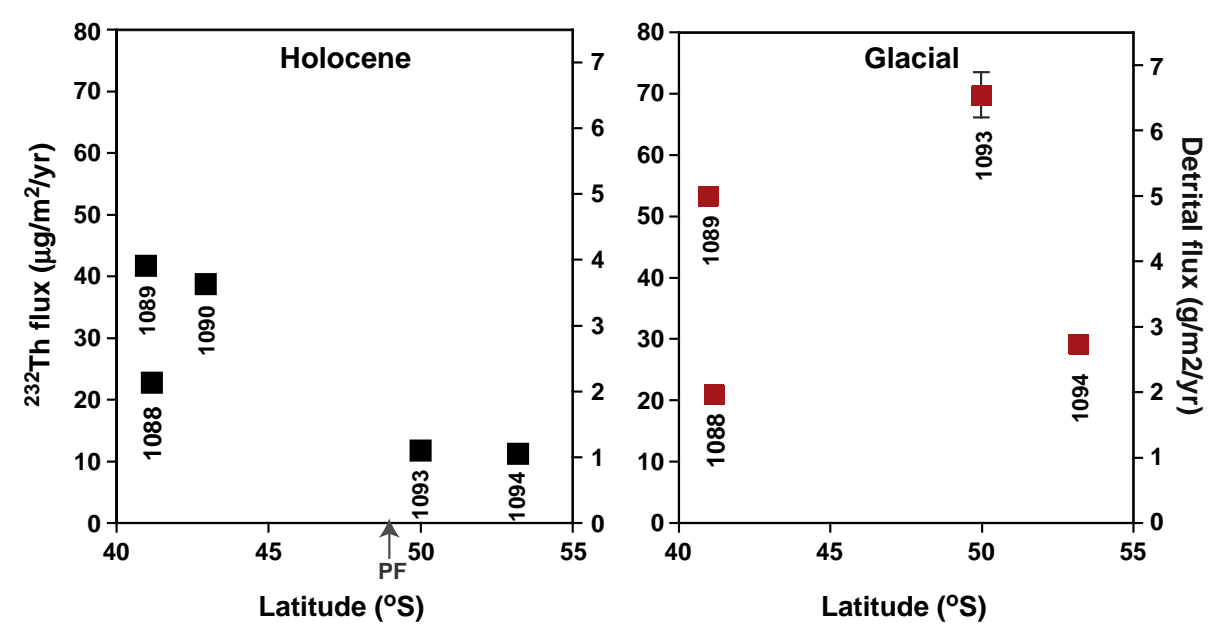

Fig. 2. ${ }^{232} \mathrm{Th}$ fluxes $\left(\mu \mathrm{g} \mathrm{m}^{-2} \mathrm{yr}^{-1}\right)$ (left axis) and detrital fluxes $\left(\mathrm{g} \mathrm{m}^{-2} \mathrm{yr}^{-1}\right.$ ) (right axis) at core sites in the eastern Atlantic sector of the Southern Ocean during the Holocene (left panel) and the LGM (right panel) calculated by ${ }^{230}$ Th-normalisation. Error bars $(2 \sigma)$ for all measurements except the LGM flux at Site 1093 are smaller than the symbol size. No LGM flux was determined for Site 1090 . 
a)

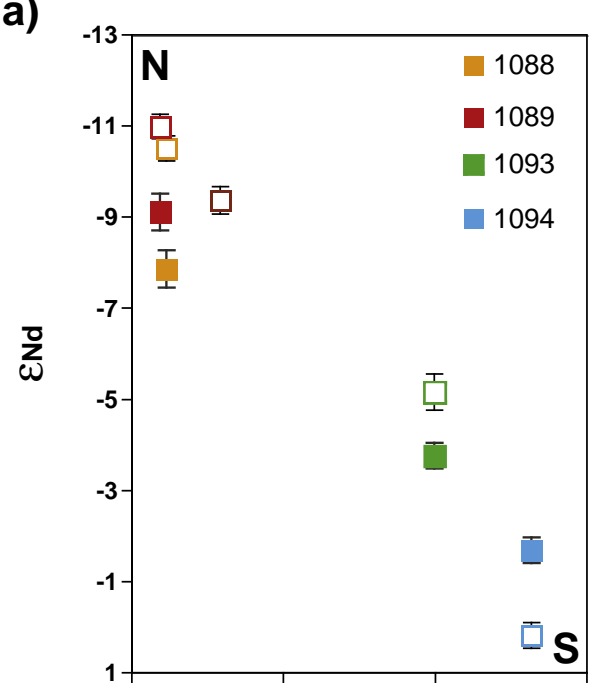

c)

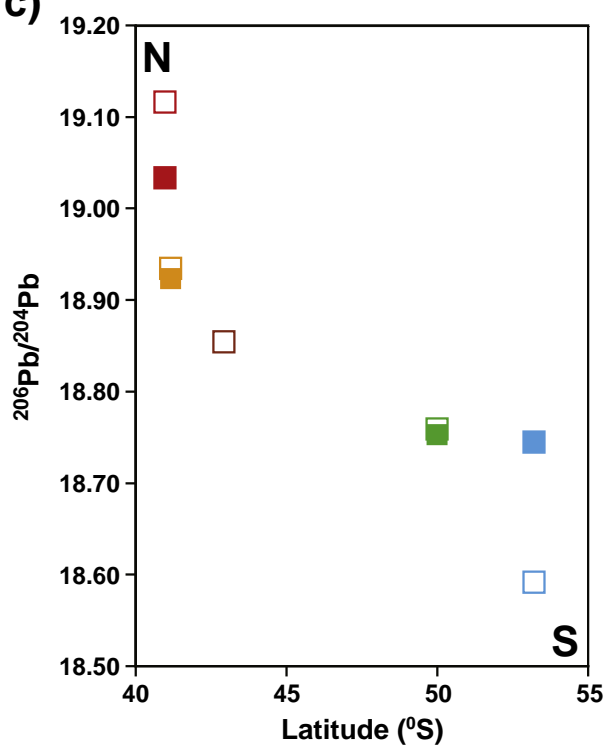

b)

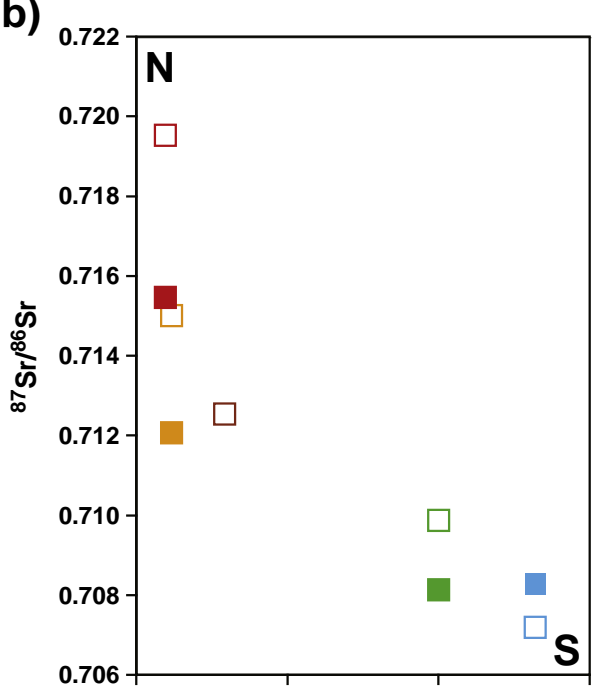

d)

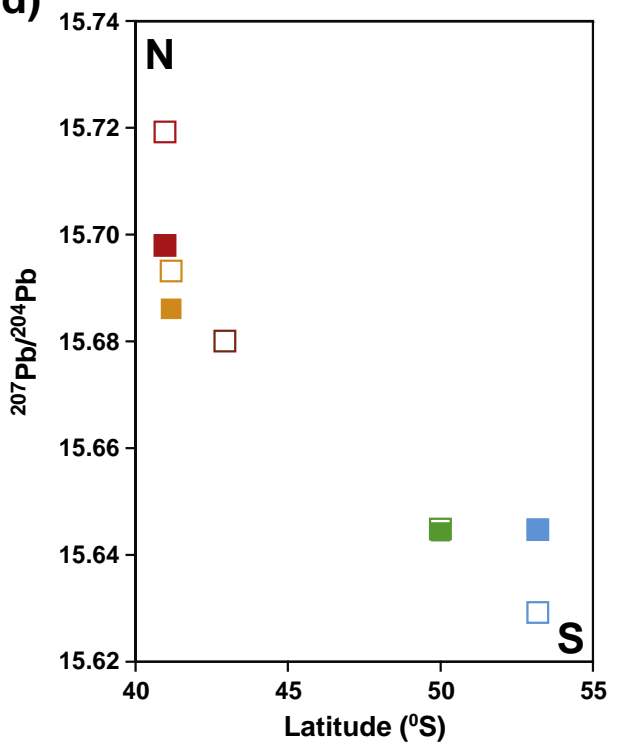

Fig. 3. a) $\varepsilon_{\mathrm{Nd}}$, b) ${ }^{87} \mathrm{Sr} /{ }^{86}{ }^{206} \mathrm{~Pb} /{ }^{204} \mathrm{~Pb}$ and d) ${ }^{207} \mathrm{~Pb} /{ }^{204} \mathrm{~Pb}$ isotope data from the ODP Leg 177 cores for the Holocene (open squares) and the LGM (filled squares) plotted against latitude; 1089 (red), 1088 (orange), 1090 (brown), 1093 (green), 1094 (blue). The $2 \sigma$ uncertainties for ${ }^{87} \mathrm{Sr} /{ }^{86} \mathrm{Sr},{ }^{206} \mathrm{~Pb} /{ }^{204} \mathrm{~Pb}$ and ${ }^{207} \mathrm{~Pb} /{ }^{204} \mathrm{~Pb}$ are smaller than the symbol sizes. (For interpretation of the references to colour in this figure legend, the reader is referred to the web version of this article.)

\section{Discussion}

The provenance data of the cores from the eastern Atlantic sector of the Southern Ocean are compared to the isotope compositions of likely source regions in Figs. 5 and 6. Southern South America is characterised by a wide range of isotope values due to the variable proportions of mantle-derived and older crust material (Pankhurst et al., 1998); with the extensive Andean Volcanic Zone displaying a wide range of radiogenic $\mathrm{Nd}$ isotopes compared to a narrow range of ${ }^{87} \mathrm{Sr} /{ }^{86} \mathrm{Sr}(\sim 0.705)$. On the eastern coast of the Antarctic Peninsula Middle Jurassic rhylolitic rocks are found, which are similar to those from the Chon Aike province in southern South America (Riley et al., 2001; 2010). Rocks from East Antarctica cover a wide range of $\varepsilon_{\mathrm{Nd}}$ values and ${ }^{87} \mathrm{Sr} /{ }^{86} \mathrm{Sr}$ ratios, with low $\varepsilon_{\mathrm{Nd}}$ values and high ${ }^{87} \mathrm{Sr} /{ }^{86} \mathrm{Sr}$ ratios originating from Archean basements rocks in East Antarctica (cf. Walter et al., 2000; Wareham et al., 1998).

\subsection{Detrital supply to the Scotia and Weddell seas}

During the LGM, lower sea levels and significant expansion of glaciers in Patagonia and the Antarctic Peninsula may have increased the supply of fine-grained glaciogenic detritus to the Scotia Sea. One possible mechanism is the seaward extension of glaciers resulting in discharge of both icebergs and meltwater plumes into the surface waters of the ocean (DaSilva et al., 1997; Marinoni et al., 2008). The concentration of IRD released by the icebergs in sediments from the Scotia Sea is highest during glacial terminations, but in general the input of coarse IRD is minor compared to the release of fine-grained particles redistributed by currents (Diekmann et al., 2000; Pugh et al., 2009). The extent of meltwater plumites is restricted to the continental margin (e.g. Lucchi et al., 2002; Pudsey, 2000). An alternative mechanism is the advance of the grounded Antarctic Peninsula and Patagonian ice sheets to the shelf edge, which resulted in the gravitational downslope transport of glaciogenic debris by slumps, slides and turbidity currents into the deep sea and its redeposition there by bottom currents (e.g. Diekmann et al., 2003; Lucchi et al., 2002; Pudsey, 2000).

The radiogenic isotope composition of core TPC290 during both the Holocene and the LGM suggests that Patagonia is the dominant source of sediment in the northern Scotia Sea, and may reflect the variability of the Patagonian Ice Cap (cf. Diekmann et al., 2000; 


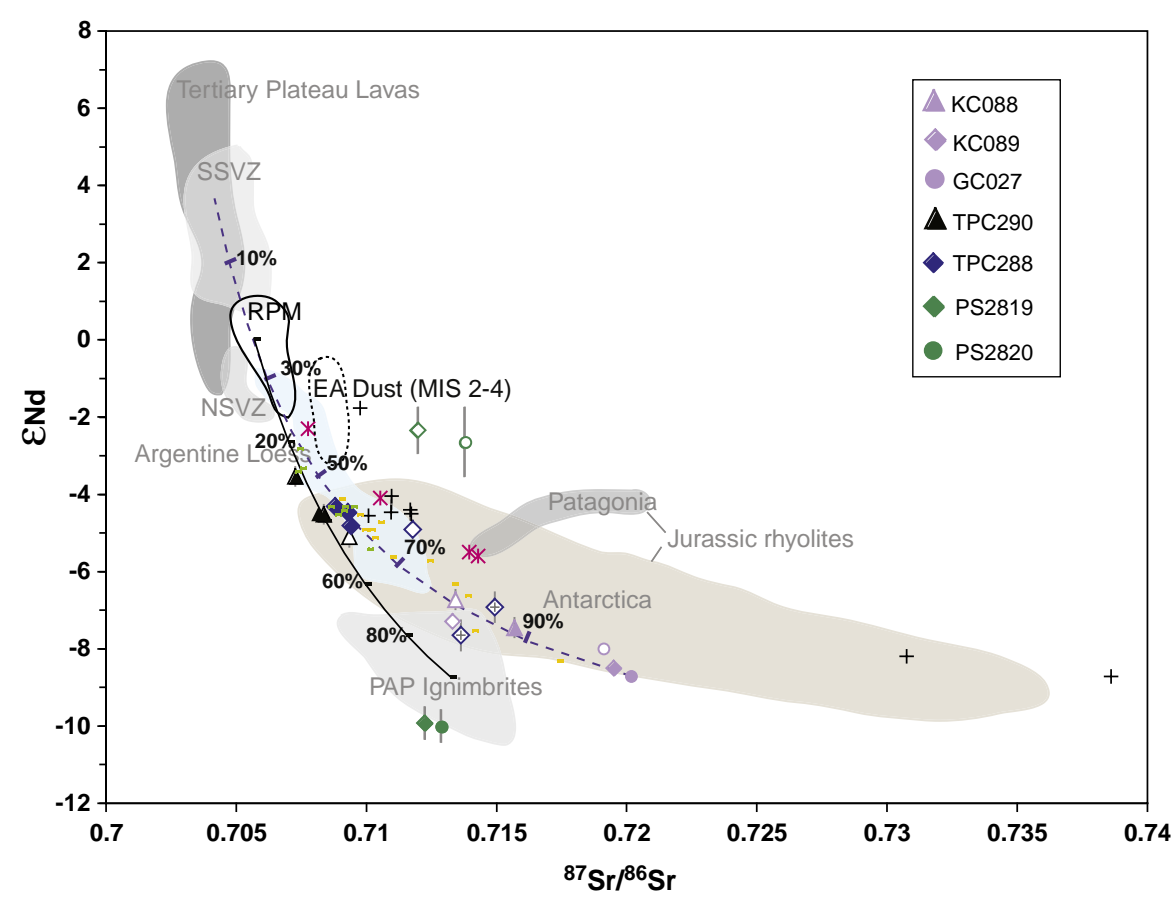

Fig. 4. $\varepsilon_{\mathrm{Nd}}$ and ${ }^{87} \mathrm{Sr} /{ }^{86} \mathrm{Sr}$ isotopic composition of bulk marine sediments from the northwestern Weddell Sea (purple symbols), northern Scotia Sea (black triangles), southern Scotia Sea (blue diamonds), and the East Antarctic continental margin (green diamonds and circles). Glacial samples are indicated by filled symbols and the Holocene samples by open symbols, with deglacial samples ( 8-13 ka) from the southern Scotia Sea highlighted by triangles with a '+'. Published compositional data from bulk sediments of the northern and southern Scotia Sea (spanning Marine Isotope Stages [MIS] 1 to MIS 6) are shown by green and yellow dots, respectively, and the corresponding composition of the clay fraction from the northern Scotia Sea sediments is indicated by pink stars (Walter et al., 2000). The potential source regions in southern South America are: Tertiary Plateau Lavas (Gorring et al., 2003; Hawkesworth et al., 1979; Kay et al., 1993), southern South Andean Volcanic Zone (SSVZ) (Parada et al., 2001), northern Southern Andean Volcanic Zone (NSVZ) (Futa and Stern, 1988), Argentine loess (Smith et al., 2003), Puna-Altiplano plateau ignimbrites (PAP) and Patagonian rhyolites (Gaiero et al., 2007). The Antarctic source region is represented by Jurassic rhyolites (Gaiero, 2007, and references within). The dotted line encircles compositional data on glacial dust in East Antarctic ice cores (MIS 2-4) (Basile et al., 1997; Delmonte et al., 2004), and the solid grey circle marks recent Patagonian material (RPM) (Gaiero et al., 2007), which includes aeolian dust and $<63 \mu \mathrm{m}$ top soils. The black "+" symbols indicate the composition of glacial sediments $(<5 \mu \mathrm{m})$ from Patagonia (Sugden et al., 2009). Isotope mixing curves: i) the dashed purple line highlights the isotope mixing between SSVZ and sediments represented by a glacial sample from the eastern Antarctic Peninsula margin (GC027) and ii) the solid black line represents isotope mixing between RPM and PAP ignimbrites. (For interpretation of the references to colour in this figure legend, the reader is referred to the web version of this article.)

Walter et al., 2000). Significant contribution of detritus from the Puna-Altiplano Plateau (PAP) ignimbrites in northern Patagonia is unlikely since it could only be delivered by atmospheric transport. The LGM to Holocene variability observed in the isotope composition of the southern Scotia Sea core TPC288, can be explained by mixing with detritus sourced from West Antarctica (Fig. 4). The isotope compositions of cores in the western Weddell Sea (KC088, KC089 and GC027) indicate that their detritus is derived from Jurassic rhyolites of the eastern Antarctic Peninsula (Pankhurst et al., 2000; Riley et al., 2001). A mixing line between the southern South Andean Volcanic Zone (SSVZ), the dominant Patagonian end-member ([Sr] 409 ppm, ${ }^{87} \mathrm{Sr} /{ }^{86} \mathrm{Sr} 0.70414$ and [Nd] $21 \mathrm{ppm}, \varepsilon_{\mathrm{Nd}}+3.7$ ) (Parada et al., 2001), and LGM sediments at site GC027 from the eastern Antarctic Peninsula margin ([Sr] $140 \mathrm{ppm},{ }^{87} \mathrm{Sr} /{ }^{86} \mathrm{Sr} 0.70414$ and [Nd] $30 \mathrm{ppm}, \varepsilon_{\mathrm{Nd}}-8.7$ ) can explain the $\mathrm{Nd}$ and $\mathrm{Sr}$ isotope variability of sediments deposited in the southern Scotia Sea (Fig. 4). Core GC027, however, is unlikely to represent the pure end-member composition for the Antarctic Peninsula, therefore the proportion of Patagonian derived sediment to the Scotia Sea is likely to be $>60 \%$. The distinct isotope composition of sediments deposited during the last deglaciation at site TPC288 (Fig. 4) is most likely linked to enhanced supply from the Antarctic Peninsula during a time of ice sheet decay.

\section{2. ${ }^{230}$ Th normalised fluxes in the eastern Atlantic sector}

\subsubsection{Holocene}

Modern day aeolian flux estimates for the Southern Ocean are some of the lowest in the world, ranging between 0.01 and $0.1 \mathrm{~g} \mathrm{~m}^{-2} \mathrm{yr}^{-1}$ (Duce et al., 1991). However, we observe Holocene ${ }^{230}$ Th-normalised detrital fluxes that range from 1.1 to $3.9 \mathrm{~g} \mathrm{~m}^{2} \mathrm{yr}^{-1}$, which indicates that aeolian supply is not the main transport mode for detritus deposited in the eastern Atlantic sector (cf. Kuhn and Diekmann, 2002). Our ${ }^{230}$ Th-normalised detrital flux estimates are comparable to those reported by Franzese et al. (2006) for the east Atlantic between the Cape Basin and Subantarctic region (1.2 to $5.8 \mathrm{~g} \mathrm{~m}^{-2} \mathrm{yr}^{-1}$ ).

The Holocene ${ }^{230} \mathrm{Th}$-normalised detrital fluxes decrease along the Leg 177 transect from north to south. The generally higher ${ }^{230} \mathrm{Th}$-normalised detrital fluxes from cores beneath the Agulhas Current (5.6 to $7.5 \mathrm{~g} \mathrm{~m}^{-2} \mathrm{yr}^{-1}$; Franzese et al., 2006) indicate that dominant supply of detrital sediment today originates from the southern Africa.

The concentration of ${ }^{232} \mathrm{Th}$ does vary in different types of sediment depending on the source, with higher concentrations in the continental crust and low concentrations in basaltic volcanic material. The detrital supply from different source regions changes between the LGM and the Holocene at our core sites (Fig. 3, Supp. Table 3), so we may underestimate the bulk detrital fluxes by using a constant ${ }^{232}$ Th concentration (e.g. Futa and Stern, (1988) reported lower Th concentrations for the Southern Andean Volcanic Zone). However, the trend of higher LGM detrital fluxes in the south of the Leg 177 transect is still robust.

\subsubsection{Last Glacial Maximum}

At all sites from the Leg 177 transect the LGM detrital flux was the same or greater than in the Holocene. The sites close to Africa show little to no change, whilst the sites close to the PF exhibit fluxes 2.5 to 6 times higher during the LGM (Fig. 2). These bulk detrital fluxes are an order of magnitude higher than those in the eastern and central equatorial Pacific (Anderson et al., 2006; Winckler et al., 2008), where detritus was transported to the equatorial Pacific predominantly by wind. This difference in detrital fluxes, suggests delivery 


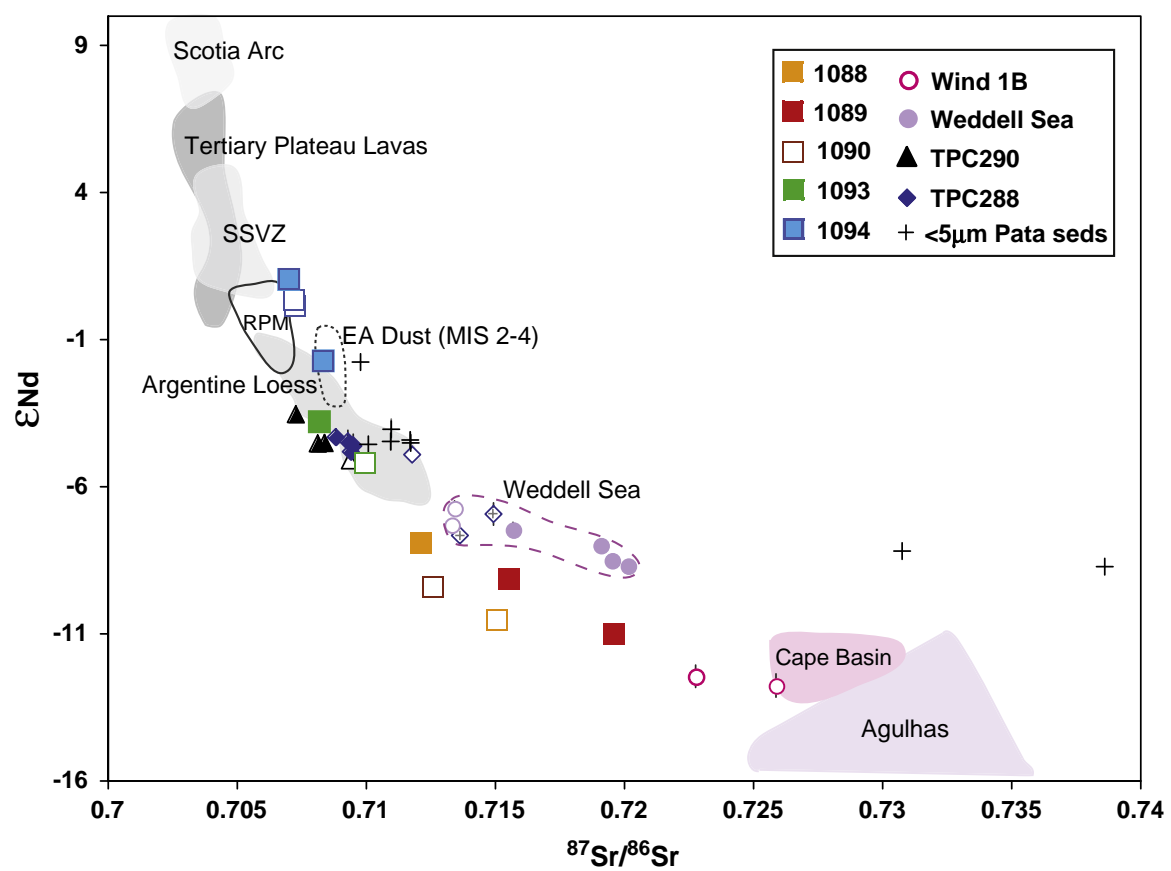

Fig. 5. $\varepsilon_{\mathrm{Nd}}$ and ${ }^{87} \mathrm{Sr} /{ }^{86} \mathrm{Sr}$ isotope composition of the Leg 177 cores and potential source regions comprising southern Africa (WIND 1B; pink circles), the northwestern Weddell Sea and the Scotia Sea. Glacial samples are marked by filled symbols and Holocene samples by open symbols (2 $\sigma$ uncertainties are smaller than the size of the symbols). Literature values for potential sources in southern South America are the same as in Fig. 4. Additionally, the isotope compositions of rocks from the Scotia Arc (GEOROC database; http:// georoc.mpch-mainz. gwdg.de), and sediments from the Cape Basin and Agulhas Current (Franzese et al., 2006) are shown. (For interpretation of the references to colour in this figure legend, the reader is referred to the web version of this article.)

of detritus by currents rather than wind, as the main glacial sediment transport mechanism in the Atlantic sector of the Southern Ocean. However, ${ }^{230}$ Th-normalisation may not correct fully for long distance sediment transport, despite the likelihood of re-equilibration of particles with thorium before burial. Preferential transport of fine-grained sediment has been shown to deliver higher adsorbed ${ }^{230} \mathrm{Th}$ concentrations due to their larger surface area (Frank et al., 1996; Kretschmer et al., 2010; McGee et al., 2010). Consequently, the estimates for detrital fluxes presented here are likely to be lower limits for the true fluxes, which may be higher by a few tens of percent (McGee et al., 2010).

Reconstructions of Patagonian glaciers show that dust peaks in the Antarctic ice cores coincide with periods when glaciers discharged directly onto outwash plains (Sugden et al., 2009). Glacial accumulation rates of terrigenous detritus in the Scotia Sea (calculated without ${ }^{230}$ Th normalisation) were ca. 3 to 9 times higher than during the Holocene (Diekmann et al., 2000). The contribution of aeolian deposition to the sedimentary budget in the Scotia Sea has been shown to be less than 3\% based on the accumulation rate of detritus in the Scotia Sea and the expected aeolian flux during the LGM (Walter et al., 2000). Therefore, the higher glacial detrital fluxes and more homogenous isotope composition of detritus observed in the eastern Atlantic sector of the Southern ocean were likely the result of increased supply of glaciogenic material due to the glacial expansion of the Patagonian ice sheet and increased current transport, with higher glacial ACC speeds (Pudsey and Howe, 1998).

4.3. Transport of Patagonian detritus to the Atlantic sector of the Southern Ocean during the last glacial period

The N-S gradient in isotope composition at the Leg 177 core sites observed in the Holocene was less pronounced during the last glacial period (Fig. 3). The Nd isotope ratios diverge from more uniform LGM values to more cratonic isotope ratios in the Holocene except for Site 1094, which is more mantle-like (Fig. 5). The glacial Pb isotope compositions of bulk sediments from the Scotia Sea and the eastern Atlantic sector of the Southern Ocean show greater spatial homogeneity across the ACC (Fig. 6). The glacial homogeneity in isotope composition of detritus along the Leg 177 transect is demonstrated by the glacial ${ }^{206} \mathrm{~Pb} /$ ${ }^{204} \mathrm{~Pb}$ and ${ }^{207} \mathrm{~Pb} /{ }^{204} \mathrm{~Pb}$ ratios at Sites 1093 and 1094 , which are similar to one another within $2 \sigma$ uncertainties (Fig. 6). This is in marked contrast to the Holocene, when the isotope ratios at Sites 1093 and 1094 are quite different. In addition, the glacial $\mathrm{Pb}$ isotope compositions of Sites 1093 and 1094 are remarkably similar to glacial Pb isotope compositions of bulk sediments from the Scotia Sea and the NW Weddell Sea (Fig. 6). Overall these data support more homogeneous sedimentary inputs distributed by the ACC to the Atlantic sector of the Southern Ocean, during the LGM than compared to Holocene. However, the higher detrital fluxes may not only be related to changes in the contribution from source regions, but may also be related to an overall increase in volume transport and current speed within the ACC (Pudsey and Howe, 1998). The systematic increase in sediment focusing in the Atlantic sector of the Southern Ocean, particularly around $45^{\circ} \mathrm{S}$, during the last glacial period supports this scenario (Frank et al., 1999), which is likely to have led to more efficient horizontal sediment transport.

During the transport of detrital particles by currents or wind, grain size sorting can result in variable isotopic compositions that differ from the isotopic compositions of the source rocks. Nd isotopes are powerful tracers of sediment provenance since they are not affected by grain size fractionation (e.g. Feng et al., 2009). In contrast, the Sr isotope system shows strong grain size dependence, with increasing ${ }^{87} \mathrm{Sr}$ / ${ }^{86} \mathrm{Sr}$ ratios with decreasing grain size fractions (Dasch, 1969). The grain size dependence of $\mathrm{Pb}$ isotopes on the other hand is not well studied. $\mathrm{Pb}$ isotopes do show significant variations with grain size, but with no specific trend (Feng et al., 2010). We observe a similar Nd, $\mathrm{Sr}$ and $\mathrm{Pb}$ isotopic range between the LGM and Holocene for the isotope composition of the bulk marine sediments in the Scotia Sea and at Site 1093 (Figs. 5, 6). This data suggests that grain size fractionation does not control the changes in isotope composition in the Atlantic sector of the Southern Ocean. The LGM to Holocene ${ }^{87} \mathrm{Sr} /{ }^{86} \mathrm{Sr}$ changes observed in the detritus of the Leg 177 cores are associated with variations in $\varepsilon_{\mathrm{Nd}}$, which are not affected by sorting (Goldstein et al., 1984). The ${ }^{87} \mathrm{Sr} /{ }^{86} \mathrm{Sr}$ ratios are less radiogenic during the last glacial period than during the Holocene at 3 


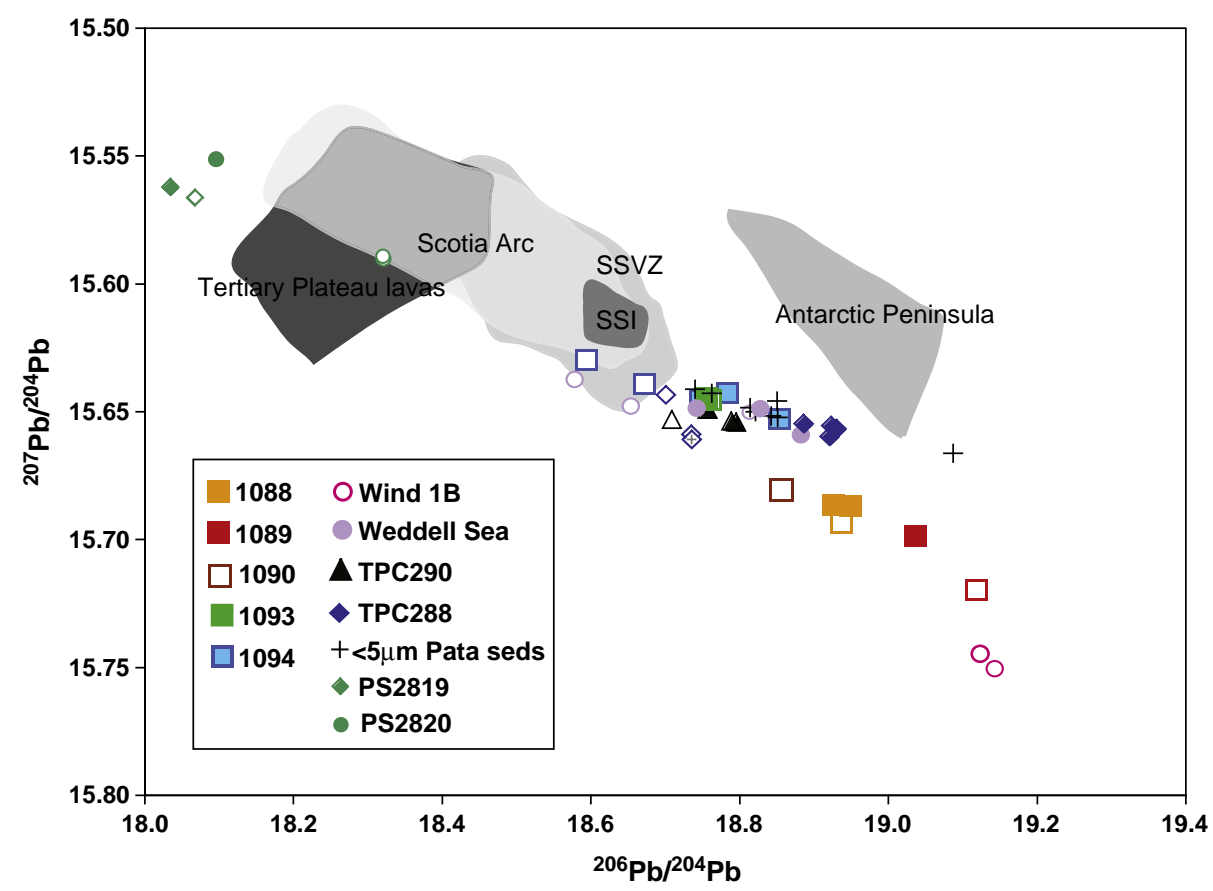

Fig. 6. $\mathrm{Pb}$ isotope composition of potential sources for sediments in the eastern Atlantic sector of the Southern Ocean. Glacial samples are marked by filled symbols and Holocene samples by open symbols ( $2 \sigma$ uncertainties are smaller than the size of the symbols). Shaded areas represent literature values for sources presented in Figs. 4 and 5 : Tertiary-Quaternary Plateau lavas in South America (Gorring et al., 2003), SSVZ, the Scotia Arc region (GEOROC database; http://georoc.mpch-mainz.gwdg.de) and the Antarctic Peninsula (which is only represented by basalts from Seal nunataks, Hole et al., 1993). Data for the South Sandwich Islands (SSI) are from bulk detrital grains and glasses from tephra-rich IRD layers in sediments from Site 1094 (Nielsen et al., 2007). There is only limited Pb isotope data from potential source areas.

of the 4 core sites, which is the opposite change to be expected, if grain size fractionation during transport was the dominant control. This implies a sediment sourcing control rather than grain size fractionation. Furthermore, since Nd isotopes do not show large variations due to climate fluctuations (e.g. Meyer et al., 2011), the LGM to Holocene $\varepsilon_{\mathrm{Nd}}$ variability provides a robust indication for changes in sediment sourcing rather than changes in the weathering regime. The lack of grain size control on the bulk sediment isotopic composition may result from the high bottom current speed $(>10 \mathrm{~cm} / \mathrm{s}$ ) of the ACC (Pudsey, 1992), which enables transport of all particles with a grain size $<1 \mathrm{~mm}$ (cf. Frank et al., 1995).

The $\mathrm{Sr}$ isotope composition of the glacial Patagonian sediments $(<5 \mu \mathrm{m})$ clearly shows fractionation associated with finer grain sizes as demonstrated by Gaiero (2007). The ${ }^{87} \mathrm{Sr} /{ }^{86} \mathrm{Sr}$ isotope ratios are offset to more radiogenic values than the glacial bulk sediments of the Scotia Sea (Fig. 5). In contrast, the glacial $\mathrm{Nd}$ and $\mathrm{Pb}$ isotope ratios of the bulk sediments from the Scotia Sea and $<5 \mu \mathrm{m}$ sediments from Patagonian are very similar (Figs. 5, 6). More work is required to understand how $\mathrm{Pb}$ isotopes vary with grain size, but the data presented here suggests no major differences with grain size.

We modelled the LGM to Holocene change in isotopic composition at Sites 1088 and 1089 using a two end-member mixing model for Nd and $\mathrm{Sr}$ isotopes (Supp Fig. 1). The southwest end-member was estimated by using the average values measured on the Scotia Sea sediments to define the isotope composition of detritus delivered by the ACC. For the northern end-member, we consider a range of values for sediments sourced from southern Africa: i) the isotope signature of detritus defined by the sediment composition of the WIND 1B core; ii) the isotope composition of the "Agulhas end-member", i.e. of detritus carried by the Agulhas Current, as defined by Franzese et al. (2006). The glacial to Holocene variability at Site 1089 is best explained by mixing with WIND 1B, whereas that at Site 1088 is best explained by mixing with the Agulhas end-member for Site 1088. The mixing models suggest that the proportion of detritus delivered from the Scotia Sea (i.e. of terrigenous material derived originally from Patagonia) was 15-25\% greater during the glacial period than during the Holocene.

Temporal variability in the strength of the Agulhas Current, which transports cratonic-derived material from southern Africa to the Atlantic sector of the Southern Ocean, has been proposed to explain the evolution in isotope composition of marine sediments at nearby sites (Franzese et al., 2006). We have shown that higher glacial detrital fluxes in the eastern Atlantic sector of the Southern Ocean were associated with increased delivery of terrigenous material from Patagonia by the ACC. During the LGM, increased eastward current-transport of fine-grained sediment can explain our data without invoking a reduction in cratonic-derived sediment input to the Cape Basin by a weaker Agulhas Current (Franzese et al., 2006; 2009) or a reduction in southward sediment supply in response to reduced influx of North Atlantic Deep Water (NADW) (e.g. Bayon et al., 2003; Diekmann et al., 2003). Therefore, the homogenous sediment provenance and the higher fluxes at the Leg 177 sites during the LGM can be fully and most simply explained by higher input of glaciogenic detritus from Patagonia and increased transport by the ACC.

\subsection{Evidence for an LGM-Holocene shift in the position of the ACC fronts?}

The circulation of the ACC is controlled by the intensity of westerly winds and bottom topography, which drive its zonal flow (Rintoul et al., 2001). In the Scotia Sea, the positions of the ACC fronts are mainly controlled by the seafloor topography and therefore unlikely to have changed on glacial-interglacial timescales (Pudsey and Howe, 1998; Naveria-Garabato et al., 2002). However, this is not necessarily the case in the entire Atlantic sector of the Southern Ocean. Our data suggests that the ACC controls the dispersal of terrigenous material to the eastern Atlantic sector of the Southern Ocean (Fig. 7). Particle sinking velocities within the PF region (averaging $157 \pm 87 \mathrm{~m}$ day $^{-1}$ ) (Fischer et al., 2002) suggest that deep ACC transport is likely to be the main 


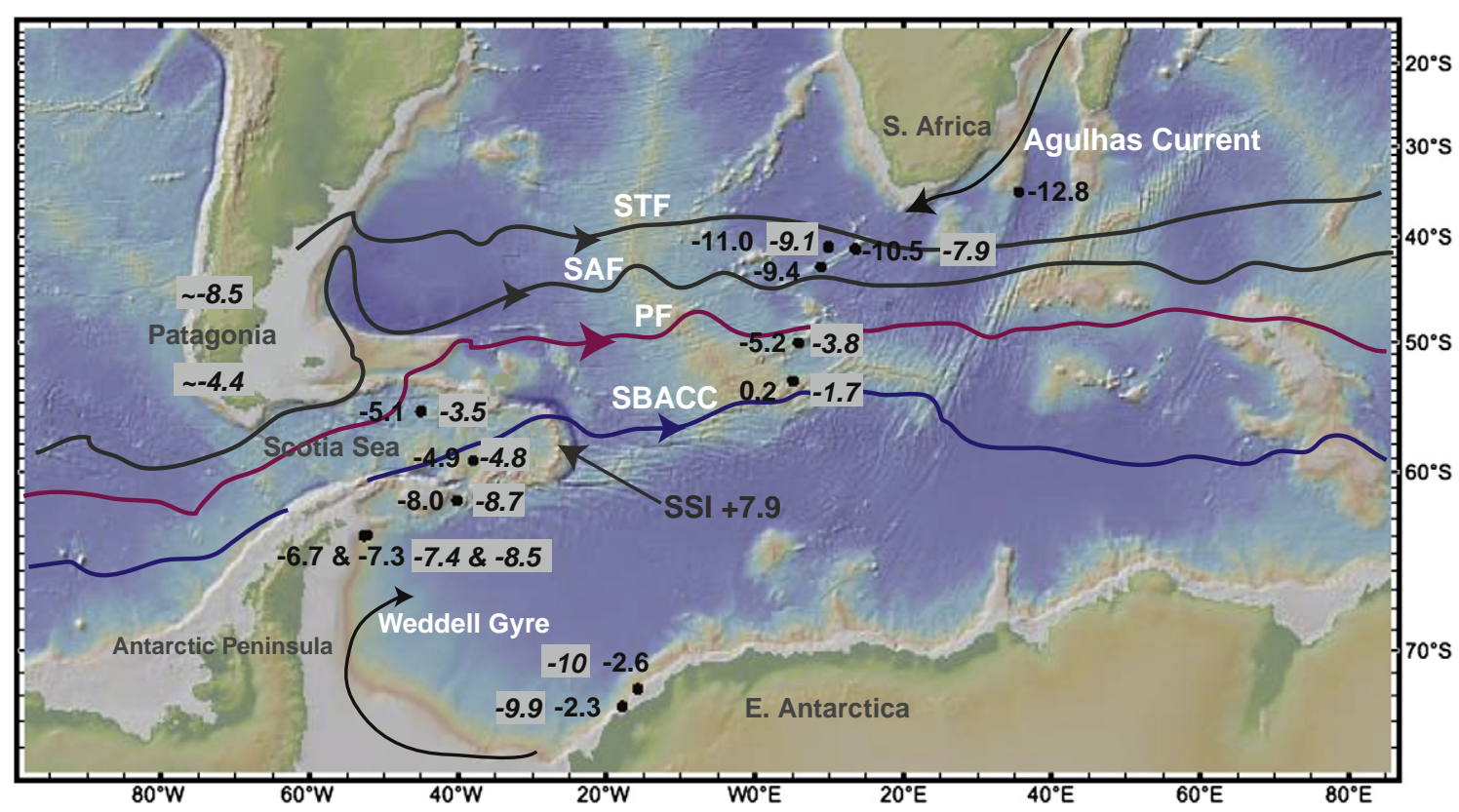

Fig. 7. Modern day position of the ACC fronts, with $\varepsilon_{\mathrm{Nd}}$ values shown for the Holocene (regular numbers) and LGM (numbers in italics, in grey boxes) for all cores analysed in this study and the isotope composition of detritus from the SSI (Nielsen et al., 2007). (Base map: http://www.geomapapp.org).

mechanism for long distance transport within the ACC. In addition, ballasting affects between biogenic and detrital particles probably increase particle sinking velocities (Fischer and Karakas, 2009) and thus reduce long distance transport of detritus in the surface waters. Furthermore, in the eastern Atlantic sector of the Southern Ocean lateral sediment redistribution by the ACC was locally up to 6.5 times greater than the vertical rain rates during the LGM (Frank et al., 1996).

The isotope compositions of glacial and Holocene sediments at Site 1093 and upstream within the ACC at site TPC290 in the northern Scotia Sea are very similar. At Sites 1093 and 1094, the sediments do not indicate a dominant supply of detritus from East Antarctica, probably because the SBACC acts as an effective barrier preventing entrainment of detritus from this source region (Fig. 7). At present, bottom currents and icebergs transport East Antarctic detritus as far as the central Weddell Sea and southern Scotia Sea (Diekmann and Kuhn, 1999; Walter et al., 2000). During interglacial periods only very large, and thus rare icebergs from East Antarctica are capable of reaching the eastern Atlantic sector of the Southern Ocean, while IRD deposition from this source increased during glacial periods (Teitler et al., 2010).

The more mantle-derived isotope composition during the Holocene at Site 1094, compared to Site 1093 and the Scotia Sea cores (Figs. 4-6) can be attributed to the supply of detritus sourced from the South Sandwich Islands. This detritus is advected along the flow path of the ACC both in suspension and incorporated as IRD in icebergs and/or sea-ice floes (Nielsen et al., 2007). At the LGM, Site 1094 was covered by winter sea-ice and perhaps sporadically even by perennial sea ice (Bianchi and Gersonde, 2004), probably implying more variable detrital input with supply from southern America dominating during the ice free months and IRD supply from sources in Antarctica and the South Sandwich Islands (cf. Nielsen et al., 2007) prevailing during the sea-ice season.

Analyses of diatom and radiolarian assemblages and accumulation rates of opal and biogenic barium in sediment cores from the eastern Atlantic sector of the Southern Ocean have indicated a glacial northward shift of the PF by $\sim 3-5^{\circ}$ of latitude (e.g. Brathauer and Abelmann, 1999; Frank et al., 2000; Gersonde et al., 2003, 2005; Nürnberg et al., 1997). The similarity in the isotope composition of sediments from Site 1093 and the Scotia Sea, however, does not conclusively support a major northward displacement of the PF during the LGM and thus may be consistent with the glacial reconstruction by Matsumoto et al. (2001). On the other hand, the higher glacial proportion of Patagonian derived detritus observed at Sites 1088 and 1089 may suggest a northward displacement of the ACC fronts. However, this cannot be distinguished from the more widespread dispersal of Patagonian detritus during the last glacial due to increased glaciogenic supply and higher speeds and volume transport of the ACC.

Higher input of terrigenous detritus to the surface waters of the Fe-starved pelagic regions of the Southern Ocean during the LGM should have increased biological productivity. For all sectors of the Southern Ocean, export production during the LGM appears to have increased in the region north of the modern PF but decreased to the south (Anderson et al., 2002; Chase et al., 2003; Frank et al., 2000; Kumar et al., 1995). Higher productivity in the last glacial period could have resulted from enhanced aeolian dust supply, yielding higher levels of bioavailable Fe in the surface waters (e.g. Kumar et al., 1995). This scenario was recently supported for Site 1090 by MartinezGarcia et al. (2009, 2011). The data presented here, however, indicates that ACC transport was the dominant mode for the supply of Patagonian-sourced detritus to the glacial Southern Ocean. Deep current transport is most likely, given ballasting between detritus and biogenic particles, although greater volume transport of the ACC during the LGM may have increased eastward displacement of particles carried in the surface waters. During the LGM, increased glaciogenic supply of detritus to the Scotia Sea, combined with lower sea levels and therefore greater interaction between the shelves and ocean currents, may have resulted in Fe enrichment of deep waters. Today, relatively high Fe concentrations in surface waters are observed in the Polar Front region of the Atlantic sector of the Southern Ocean. These higher Fe contents are associated with vigorous wind-driven upwelling and eddy diffusion (de Baar et al., 1995) and are suggested to result from the energetic interaction between the Polar Frontal jet and the South America shelf and slope sediments (Loscher et al., 1997). Increased upwelling and deep mixing during the last glacial period could supply this sedimentary source of Fe to the surface waters. However, reduced upwelling and increased stratification of the glacial Southern Ocean have been suggested as mechanisms to sequester $\mathrm{CO}_{2}$ away from the atmosphere and into the deep ocean (e.g. Jaccard et al., 2005, Sigman et al., 2010; Watson and Garabato, 2006). Increased glacial stratification, however, is questioned at least for the LGM sea-ice covered zone of the 
Southern Ocean (e.g. Hillenbrand and Cortese, 2006; Sigman et al., 2010). The contributions of a higher glaciogenic input and increased sediment transport within the deep ACC to elevated Fe concentrations in surface waters of the Southern Ocean at the LGM requires further investigation.

\section{Conclusions}

- Detrital inputs to the eastern Atlantic sector of the Southern Ocean were more homogenous during the LGM than during the Holocene.

- Increased supply of glaciogenic detritus from Patagonian and the Antarctic Peninsula ice sheets during the LGM is reflected in the provenance signal of cores from the eastern Atlantic sector of the Southern Ocean.

- The higher glacial detrital fluxes in the eastern Atlantic sector of the Southern Ocean are attributed to changes in environmental conditions in southern South America related to lower sea level, formation of mobile outwash plains, and increased supply of glaciogenic debris by expanded Patagonian and Antarctic Peninsula ice sheets.

- We suggest that particle transport within the ACC was the most important supply mechanism at the LGM, because the ACC probably had a higher transport volume due to increased current speed.

Supplementary materials related to this article can be found online at doi:10.1016/j.epsl.2011.10.007.

\section{Acknowledgements}

We thank James Smith and Claire Allen for their help in sampling the cores recovered by the British Antarctic Survey and Gerhard Kuhn from the Alfred Wegener Institute for Polar and Marine Research (Bremerhaven) for providing the samples of cores PS2819 and PS2820. David Sugden is acknowledged for providing the glacial Patagonian samples. We thank Hazel Chapman for her help with the Sr isotope analyses and Fatima Kahn and Jo Clegg for their lab support. Albert Galy and Jason Day are acknowledged for their support with the ICP-MS facilities. Moreover, we thank the editor Gideon Henderson, reviewer Martin Frank and two anonymous referees for their helpful comments, which improved the manuscript. This work was supported by UK NERC grant NE/D002206/1, RG43765/LBZG021 "Assessing the role of ocean circulation in rapid climate change through the novel integration of high-resolution proxy records".

\section{References}

Anderson, R.F., Chase, Z., Fleisher, M.Q., Sachs, J., 2002. The Southern Ocean's biological pump during the Last Glacial Maximum. Deep-Sea Research. II 49, 1909-1938.

Anderson, R.F., Fleisher, M.Q., Lao, Y., 2006. Glacial-interglacial variability in the delivery of dust to the central equatorial Pacific Ocean. Earth Planet. Sci. Lett. 242, 406. Bacon, M., 1984. Glacial to interglacial changes in carbonate and clay sedimentation in the Atlantic Ocean estimated from ${ }^{230} \mathrm{Th}$ measurements. Isot. Geosci. 2, 97-111.

Basile, I., Grousset, F.E., Revel, M., Petit, J.R., Biscaye, P.E., Barkov, N.I., 1997. Patagonian origin of glacial dust deposited in East Antarctica (Vostok and Dome C) during glacial stages 2, 4 and 6. Earth Planet. Sci. Lett. 146, 573-589.

Bayon, G., German, C.R., Boella, R.M., Milton, J.A., Taylor, R.N., Nesbitt, R.W., 2002. An improved method for extracting marine sediment fractions and its application to Sr and Nd isotopic analysis. Chem. Geology. 187, 179-199.

Bayon, G., German, C.R., Nesbitt, R.W., Bertrand, P., Schneider, R.R., 2003. Increased input of circumpolar deep water-borne detritus to the glacial SE Atlantic Ocean. Geochem. Geophys. Geosyst. 4. doi:10.1029/2002GC000371.

Bianchi, C., Gersonde, R., 2004. Climate evolution at the last deglaciation: the role of the Southern Ocean. Earth Planet. Sci. Lett 228, 407-424.

Bickle, M.J., Bunbury, J., Chapman, H.J., Harris, N.B.W., Fairchild, I.J., Ahmad, T., 2003. Fluxes of Sr into the headwaters of the Ganges. Geochim. Cosochim. Acta. 67 (14), 2567-2584.

Brathauer, U., Abelmann, A., 1999. Late Quaternary variations in sea surface temperatures and their relationship to orbital forcing recorded in the Southern Ocean (Atlantic sector). Paleoceanography 14, 135-148.

Chase, Z., Anderson, R.F., Fleisher, M.Q., Kubik, P.W., 2003. Accumulation of biogenic and lithogenic material in the Pacific sector of the Southern Ocean during the past 40000 years. Deep-Sea Reseach. 50, 799-832.
Chester, R., Hughes, M.J., 1967. A chemical technique for the separation of ferromanganese minerals, carbonate minerals and adsorbed trace elements from pelagic sediments. Chem. Geol. 2, 249-262.

Dasch, E.J., 1969. Strontium isotopes in weathering profiles, deep-sea sediments, and sedimentary rocks. Geochim. Cosmochim. Acta 33 (12), 1521-1552. doi:10.1016/ 0016-7037(69)90153-7.

DaSilva, J.L., Anderson, J.B., Stravers, J., 1997. Seismic facies changes along a nearly continuous $24^{\circ}$ latitudinal transect: the fjords of Chile and the northern Antarctic Peninsula. Mar. Geol. 143, 103-123.

de Baar, H.J.W., de Jong, J.T.M., Bakker, D.C.E., Loscher, B.M., Veth, C., Bathmann, U.V., Smetacek, V., 1995. Importance of iron for phytoplankton blooms and CO2 drawdown in the Southern Ocean. Nature 373, 412-415.

Delmonte, B., Basile-Doelsch, I., Petit, J.R., Maggi, V., Revel-Rolland, M., Michard, A., Jagoutz, E., Grousset, F., 2004. Comparing the EPICA and Vostok dust records during the last 220,000 years: stratigraphical correlation and provenance in glacial periods. Earth Sci. Rev. 66 (1-2), 63-87.

Delmonte, B., Baroni, C., Andersson, P.S., Schoberg, H., Hansson, M., Aciego, S., Petit, J.R., Albani, S., Mazzola, C., Maggi, V., Frezzotti, M., 2010. aeolian dust in the Talos Dome ice core 9East Antarctica, Pacific/Ross (Sea sector): Victoria Land versus remote sources of the last two climate cycles. J. Quat. Sci. DOI: 10.1002/jqs.1418.

Diekmann, B., 2007. Sedimentary patterns in the late Quaternary Southern Ocean. Deep-Sea. Res. II 54, 2350-2366.

Diekmann, B., Kuhn, G., 1999. Provenance and dispersal of glacial-marine surface sediments in the Weddell Sea and adjoining areas, Antarctica: ice-rafting versus current transport. Marine Geology 158, 209-231.

Diekmann, B., Kuhn, B.G., Rachold, V., Abelmann, A., Brathauer, U., Fütterer, D.K., Gersonde, R., Grobe, H., 2000. Terrigenous sediment supply in the Scotia Sea (Southern Ocean): response to Late Quaternary ice dynamics in Patagonia and the Antarctic Peninsula. Palaeogeogr. Palaeoclimatol. Palaeoecol. 162, 357-387.

Diekmann, B., Fütterer, D.K., Grobe, H., Hillenbrand, C.D., Kuhn, G., Michels, K., Petschick, R., Pirrung, M., 2003. Terrigenous sediment supply in the polar to temperate South Atlantic: land-ocean links of environmental changes during the late Quaternary. In: Wefer, G., Mulitza, S., Ratmeyer, V. (Eds.), The South Atlantic in the Late Quaternary: Reconstruction of Material Budget and Current Systems. Springer, Berlin, Heidelberg, New York, Tokyo, pp. 375-399.

Duce, R.A., Liss, P.S., Merrill, J.T., Atlas, E.L., Buat-Menard, P., Hicks, B.B., Miller, J.M., Prospero, J.M., Arimoto, R., Church, T.M., chneider, B., Soudine, A., Tokos, J.J., Tsunogai, S., Wollas, R., Zhou, M., 1991. The atmospheric input of trace species to the world ocean. Global Biogeochem. Cycles 5 (3), 193-259.

Edwards, R.L., Chen, J.H., Wasserburg, G.J., 1986. 238U-234U-230Th-232Th systematics and the precise measurement of time over the past 500000 years. Earth Planet. Sci. Letters. 81 (2-3), 175-192.

Feng, J.-L., Zhu, L.-P., Zhen, X.-L., Hu, Z.-G., 2009. Grain size effect on Sr and Nd isotopic compositions in eolian dust: implications for tracing dust provenance and $\mathrm{Nd}$ model age. Geochemical Journal 43, 123-131.

Feng, J.-L., Hu, Z.-G., Cui, J.-Y., Zhu, L.-P., 2010. Distributions of lead isotopes with grain sizes in eolian deposits. Terra Nova 22, 257-263.

Fischer, G., Karakas, G., 2009. Sinking rates and ballast composition of particles in the Atlantic Ocean: implications for the organic carbon fluxes to the deep ocean. Biogeoscience 6, 85-102.

Fischer, G., Gersonde, R., Wefer, G., 2002. Organic carbon, biogenic silica and diatom fluxes in the marginal winter sea-ice zone and in the Polar Front Region: interannual variations and differences in composition. Deep Sea Res. II 49 (1721-1745), 2002.

Francois, R., Frank, M., Rutgers van der Loeff, M.M., Bacon, M.P., 2004. Th-230 normalization: an essential tool for interpreting sedimentary fluxes during the late Quaternary. Paleoceanography 19 (1).

Frank, M., Eisenhauer, A., Bonn, W.J., Walter, P., Grobe, H., Kubik, P.W., Dittrich-Hannen, B., Mangini, A., 1995. Sediment redistribution versus paleoproductivity change: Weddell Sea Margin sediment stratigraphy for the last 250,000 years deduced from ${ }^{230} \mathrm{Th}_{\mathrm{xs}},{ }^{10} \mathrm{Be}$ and biogenic barium profiles. Earth Planet. Sci. Lett. 136, 556-573.

Frank, M., Gersonde, R., Rutgers van der Loeff, M., Kuhn, G., Mangini, A., 1996. Late Quaternary sediment dating and quantification of lateral sediment redistribution applying 230Thex: A study from the eastern Atlantic sector of the Southern Ocean. Geologische Rundschau 85, 554-566.

Frank, M., Gersonde, R., Mangini, A., 1999. Sediment redistribution, 230Thexnormalization and implications for the reconstruction of particle flux and export paleoproductivity. In: Fischer, G., Wefer, G. (Eds.), Use of Proxies in Paleoceanography: Examples from the South Atlantic. Springer-Verlag, Berlin, Heidelberg, pp. 409-426.

Frank, M., Gersonde, R., Rutgers van der Loeff, M., Bohrmann, G., Nürnberg, C.C., Kubik, P.W., Suter, M., Mangini, A., 2000. Similar glacial and interglacial export bioproductivity in the Atlantic sector of the Southern Ocean: multiproxy evidence and implications for glacial atmospheric CO2. Paleoceanography 15, 642-658.

Franzese, A.M., Hemming, S.R., Goldstein, S.L., Anderson, R.F., 2006. Reduced Agulhas Leakage during the Last Glacial Maximum inferred from an integrated provenance and flux study. Earth Planet. Sci. Lett. 250 (1-2), 72-88.

Franzese, A.M., Hemming, S.R., Goldstein, S.L., 2009. Use of strontium isotopes in detrital sediments to constrain the glacial position of the Agulhas Retroflection. Paleoceanography 24. doi:10.1029/2008PA001706.

Futa, K., Stern, C.R., 1988. Sr and Nd isotopic and trace element compositions of Quaternary volcanic centers of the southern Andes. Earth Planet. Sci. Lett. 88, 253-262.

Gaiero, D.M., 2007. Dust provenance in Antarctica ice during glacial periods: from where in southern South America? Geophys. Res. Lett. 34, L17707. doi:10.1029/ 12007 GL030520. 
Gaiero, D.M., Brunet, F., Probst, J.L., Depetris, P.J., 2007. A uniform isotopic and chemical signature of dust exported from Patagonia: rock sources and occurrence in southern environments. Chem. Geol. 238 (1-2), 107-120.

Gersonde, R., Abelmann, A., Brathauer, U., 2003. Last glacial sea surface temperatures and sea-ice extent in the Southern Ocean (Atlantic-Indian sector): a multiproxy approach. Paleoceanography 18, 1061. doi:10.1029/2002PA000809.

Gersonde, R., Crosta, X., Abelmann, A., Armand, L., 2005. Sea-surface temperature and sea ice distribution of the Southern Ocean at the EPILOG Last Glacial Maximum - a circumAntarctic view based on siliceous microfossil records. Quat. Sci. Rev. 24, 869-896.

Goldstein, S.L., O'Nions, R.K., Hamilton, P.J., 1984. A Sm-Nd isotopic study of atmospheric dusts and particulates from major river systems. Earth Planet. Sci. Lett. 70 (2), 221-236 DOI: 10.1016/0012-821X(84)90007-4.

Gorring, M., Singer, B., Gowers, J., Kay, S.M., 2003. Plio-Pleistocene basalts from the Meseta del Lago Buenos Aires, Argentina: evidence for asthenosphere-lithosphere interactions during slab window magmatism. Chem. Geol. 193 (3-4), 215-235.

Grobe, H., Mackensen, A., 1992. Late Quaternary climate cycles as recorded in sediments from the Antarctic continental margin. In: Kennett, J.P., Warnke, D.A (Eds.), The Antarctic Paleoenvironment: A Perspective on Global Change Part One. : Antarctic Research Series, vol. 56. American Geophysical Union, Washington, D.C, pp. 349-376.

Grousset, F.E., Biscaye, P.E., Revel, M., Petit, J.R., Pye, K., Jossaume, S., Jouzel, J., 1992 Antarctic (Dome C) ice-core dust at 18 k.y. B.P.: isotopic constraints and origins. Earth Planet. Sci. Lett. 111, 175-182.

Grousset, F.E., Parra, M., Bory, A., Martinez, P., Bertrand, P., Shimmield, G., Ellam, R.M., 1998. Saharan wind regimes traced by the $\mathrm{Sr}-\mathrm{Nd}$ isotopic composition of subtropical Atlantic sediments: last Glacial Maximum vs today. Quat. Sci. Rev. 17, 395-409.

Halliday, A.N., Lee, D.-C., Christensen, J.N., Rehkamper, M., Yi, W., Luo, X., Hall, C.M., Ballentine, C.J., Pettke, T., Stirling, C., 1998. Applications of multiple collector-ICPMS to cosmochemistry, geochemistry, and paleoclimatology. Geochim. Cosmochim. Acta 62, 919-940.

Hawkesworth, C.J., Norry, M.J., Roddick, P.E., Baker, P.E., Francis, P.W., Thorpe, R.S. 1979. $143 \mathrm{Nd} / 144 \mathrm{Nd}, 87 \mathrm{Sr} / 86 \mathrm{Sr}$, and incompatible element variations in calcalkaline Andesites and Plateau lavas from South America. Earth Planet. Sci. Lett. $42,45-57$.

Hemming, S.R., Rasbury, E.T., 2000. Pb isotope measurements of sanidine monitor standards: implications for provenance analysis and tephrachronology. Chem. Geol. $165,331-337$.

Henderson, G.M., Heinze, C., Anderson, R.F., Winguth, A.M.E., 1999. Global distribution of the 230Th flux to ocean sediments constrained by GCM modeling. Deep-Sea Res. I 46, 1861-1893.

Hillenbrand, C.-D., Cortese, G., 2006. Polar stratification: a critical view from the Southern Ocean. Palaeogeogr. Palaeoclimatol. Palaeoecol. 242, 240-252.

Hodell, D.A., Charles, C.D. Curtis, J.H., Mortyn, P.G., Ninnemann, U.S., Venz, K.A., 2003a. [Online] In: Gersonde, R., Hodell, D.A., Blum, P. (Eds.), Proceedings of the Ocean Drilling Program, Scientific Results 177http://www.odp.tamu.edu/publications/ 177_SR/chap_09/.

Hodell, D.A., Venz, K.A., Charles, C.D., Ninnemann, U.S., 2003b. Pleistocene vertical carbon isotope and carbonate gradients in the South Atlantic sector of the Southern Ocean. Geochem. Geophys. Geosyst. 4 (1), 1004. doi:10.1029/2002GC000367.

Hoffmann, S.S., McManus, J.F., 2007. Is there a thorium-230 deficit in Arctic sediments? Earth Planet. Sci. Lett. 258, 516-527.

Hole, M.J., Kempton, P.D., Millar, I.L., 1993. Trace elements and isotopic characteristics of small-degree melts of the asthenosphere: evidence from the alkalic basalts of the Antarctic Peninsula. Chem. Geology. 109, 51-68

Jaccard, S.L., Haug, G.H., Sigman, D.M., Pedersen, T.F., Thierstein, H.R., Rohl, U., 2005 Glacial/Interglacial changes in Subantarctic North Pacific Stratification. Science 308, 1003-1006.

Jacobsen, S.B., Wasserburg, G.J., 1980. Sm-Nd isotopic evolution of chondrites. Earth Planet. Sci. Lett. 50 (1), 139-155.

Jordan, R.W., Pudsey, C.J., 1992. High-resolution diatom stratigraphy of Quaternary sediments from the Scotia Sea. Mar. Micropaleontol. 19, 201-237.

Kay, S., Ramos, V.A., Marquez, M., 1993. Evidence in Cerro Pamp volcanic rocks for slabmelting prior to ridge-trench collision in Southern South America. J. Geol. 101, 703-714.

Kretschmer, et al., 2010. Grain size effects on 230Thxs inventories in opal-rich and carbonate-rich marine sediments. Earth Planet. Sci. Lett. 294, 131-142.

Kuhn, G., Diekmann, B., 2002. Late Quaternary variability of ocean circulation in the southeastern South Atlantic inferred from the terrigenous sediment record of a drift deposit in the southern Cape Basin (ODP Site 1089). Palaeogeogr. Palaeoclimatol. Palaeoecol. 182, 287-303.

Kumar, N., Anderson, R.F., Mortlock, R.A., Froelich, P.N., Kubik, P., Dittrich-Hannen, B. Suter, M., 1995. Increased biological productivity and export production in the glacial Southern Ocean. Nature 378, 675-680.

Lambert, F., Delmote, B., Petit, J.R., Bigler, M., Kaufmann, P.R., Hutterli, M.A., Stocker T.F., Ruth, U., Steffensen, J.P., Maggi, V., 2008. Dust-climate coupling over the past 800000 years from the EPICA Dome C ice core. Nature 452. doi:10.1038/ nature06763.

Latimer, J.C., Hendy, I.L., Gleason, J.D., Blum, J.D., 2006. Glacial-interglacial terrigenous provenance in the southeastern Atlantic Ocean: the importance of deep-wate sources and surface currents. Geology 34, 545-548.

Li, F., Ginoux, P., Ramaswamy, V., 2008. Distribution, transport, and deposition of mineral dust in the Southern Ocean and Antarctica: contribution of major sources. J. Geophys. Res. 112. doi:10.1029/2007JD009190.

Loscher, B.M., de Baar, H.J.W., de Jong, J.T.M., Veth, C., Dehairs, F., 1997. The distribution of Fe in the Antarctic Circumpolar Current. Deep-Sea Res. II 44 (1-2), 143-187.
Lucchi, R.G., Rebesco, M., Camerlenghi, A., Busetti, M., Tomadin, L., Villa, G., Persico, D. Morigi, C., Bonci, M.C., Giorgetti, G., 2002. Mid-late Pleistocene glacimarine sedimentary processes of a high-latitude, deep-sea sediment drift (Antarctic Peninsula Pacific margin). Mar. Geol. 189, 343-370.

Marinoni, L., Setti, M., Salvi, C., Lopez-Galindo, A., 2008. Clay minerals in late Quaternary sediments from the south Chilean margin as indicators of provenance and palaeoclimate. Clay Miner 43, 235-253.

Martin, J.H., 1990. Glacial-interglacial CO2 change: the iron hypothesis. Paleoceanography $5(1), 1-13$

Martinez-Garcia, A., Rosell-Mele, A., Jaccard, S.L., Geibert, W., Sigman, D. M., Haug., G. H., Southern Ocean dust-climate coupling over the past four million years. Nature. doi:10.1038/nature10310

Martinez-Garcia, A., Rosell-Mele, A., Geibert, W., Gersonde, R., Masque, P., Gaspari, V., Barbante, C., 2009. Links between iron supply, marine productivity, sea-surface temperature, and $\mathrm{CO}_{2}$ over the last $1.1 \mathrm{Ma}$. Paleoceanography 24 Doi: 10.1029/ 2008 PA001657.

Matsumoto, K., Lynch-Stieglitz, J., Anderson, R.F., 2001. Similar glacial and Holocene Southern Ocean hydrography. Paleoceanography 16 (5), 445-454.

McGee, D., Marcantonio, F., McManus, J.F., Winkler, G., 2010. The response of excess 230Th and extraterrestrial $3 \mathrm{He}$ to sediment redistribution at the Blake Ridge, western North Atlantic. Earth Planet. Sci. Lett. 299, 138-149.

McManus, J.F., Anderson, R.F., Broecker, W.S., Fleisher, M.Q., Higgins, S.M., 1998. Radiometrically determined sedimentary fluxes in the sub-polar North Atlantic during the last 140,000 years. Earth Planet. Sci. Lett. 155, 29-43.

McManus, J.F., Francois, R., Gherardi, J.M., Keigwin, L.D., Brown-Leger, S., 2004. Collapse and rapid resumption of Atlantic meridional circulation linked to deglacial climate changes. Nature $428,834-837$

Meyer, I., Davies, G.R., Stuut, J.-B.W., 2011. Grain size control on Sr-Nd isotope provenance studies and impact on paleoclimate reconstructions: An example from deep-sea sediments offshore NW Africa. Geochem. Geophys. Geosyst. 12 Q03005. doi:10.1029/2010GC003355.

Naveira-Garabato, A.C., Heywood, K.J., Stevens, D.P., 2002. Modification and pathways of Southern Ocean Deep Waters in the Scotia Sea. Deep-Sea Res. I 49, 681-705.

Nielsen, S.H.H., Hodell, D.A., Kamenov, G., Guilderson, T., Perfit, M.R., 2007. Origin and significance of ice-rafted detritus in the Atlantic sector of the Southern Ocean. Geochem. Geophys. Geosyst. 8, Q12005. doi:10.1029/2007GC001618.

Nürnberg, C.C., Bohrmann, G., Schlüter, M., Frank, M., 1997. Barium accumulation in the Atlantic sector of the Southern Ocean: results from 190,000-year records. Paleoceanography 12, 594-603.

Pankhurst, R.J., Leat, P.T., Sruoga, P., Rapela, C.W., Marquez, M., Storey, B.C., Riley, T.R. 1998. The Chon-Aike silicic igneous province of Patagonia and related rocks in Antarctica: a silicic large igneous province. J. Volcanol. Geotherm. Res. 81, 113-136.

Pankhurst, R.J., Riley, T.R., Fanning, C.M., Kelley, S.P., 2000. Episodic silicic volcanism in Patagonia and the Antarctic Peninsula: chronology of magmatism associated with break-up of Gondwana. J. Petrol. 41, 605-625.

Parada, M.A., Lahsen, A., Palacios, C., 2001. Ages and geochemistry of Mesozoic-Eocene back-arc volcanic rocks in the Aysén region of the Patagonian Andes. Chile. Rev. Geol. Chile 28 (1), 25-46.

Petit, J.R., Jouzel, J., Raynaud, D., Barkov, N.I., Barnola, J.M., Basile, I., Bender, M., Chappellaz, J., Davis, M., Delaygue, G., Delmotte, M., Kotlyakov, V.M., Legrand, M., Lipenkov, V.Y., Lorius, C., Pe'pin, L., Ritz, C., Saltzman, E., Stievenard, M., 1999. Climate and atmospheric history of the past 420,000 years from the Vostok ice core. Antarct. Nat. 399, 429-436.

Pichat, S., Sims, K.W., François, R., McManus, J.F., Albarède, F., 2004. Lower export production during glacial periods in the equatorial Pacific as derived from $(231 \mathrm{~Pa} / 230 \mathrm{Th}) \mathrm{xs}$, measurements in deep-sea sediments. Paleoceanography 19. doi:10.1029/2003PA000994.

Piotrowski, A.M., Goldstein, S.L., Hemming, S.R., Fairbanks, R.G., 2004. Intensity and variability of ocean thermohaline circulation during the last deglaciation. Earth Planet. Sci. Lett. 225, 205-220.

Prospero, J.M., Ginoux, P., Torres, O., Nicholson, S.E., 2002. Environmental characteristics of global sources of atmospheric soil dust derived from the NIMBUS-7 TOMS absorbing aerosol product. Rev. Geophys. 40 (2).

Pudsey, C.J., 1992. Late Quaternary changes in Antarctic bottom water velocity inferred from sediment grain size in the northern Weddell Sea. Mar. Geol. 107, 9-33.

Pudsey, C.J., 2000. Sedimentation on the continental rise west of the Antarctic Peninsula over the last three glacial cycles. Mar. Geol. 167, 313-338.

Pudsey, C.J., Howe, J.A., 1998. Quaternary history of the Antarctic Circumpolar Current: evidence from the Scotia Sea. Mar. Geol. 148, 83-112.

Pugh, R.S., McCave, I.N., Hillenbrand, C.D., Kuhn, G., 2009. Circum-Antarctic age modeling of Quaternary marine cores under the Antarctic Circumpolar Current: ice-core dust-magnetic correlation. Earth Planet. Sci. Lett. 284, 112-123.

Riley, T.R., Leat, P.T., Pankhurst, R.J., Harris, C., 2001. Origins of large volume rhyolitic volcanism in Antarctica Peninsula and Patagonia by crustal melting. J. Petrol. 42 (6), 1043-1065

Riley, T.R., Flowerdew, MJ., Hunter, M.A., Whitehouse, MJ., 2010. Middle Jurassic rhyolite volcanism of eastern Graham Land, Antarctic Peninsula: age correlations and stratigraphic relationships. Geological Magazine 147 (4), 581-595.

Rintoul, S., Hughes, C., Olbers, D., 2001. The Antarctic Circumpolar Current system. In: Siedler, G., Church, J., Gould, J. (Eds.), Ocean Circulation and Climate. Academic Press, New York, pp. 271-302.

Robinson, L.F., Noble, T.L., McManus, J.F., 2008. Measurement of adsorbed and total ${ }^{232} \mathrm{Th} /{ }^{230} \mathrm{Th}$ ratios from marine sediments. Chem. Geol. 252, 169-179.

Rutberg, R.L., Hemming, S.R., Goldstein, S.L., 2000. Reduced North Atlantic deep water flux to the glacial Southern Ocean inferred from neodymium isotope ratios. Nature 405 (6789), 935-938. 
Shipboard Scientific Party, 1999. Leg 177 summary: Southern Ocean paleoceanography. In: Gersonde, R., Hodell, D.A., Blum, P., et al. (Eds.), Proc. ODP Init. Repts., 177. College Station, TX, pp. 1-67 (Ocean Drilling Program).

Sigman, D.M., Hain, M.P., Haug, G.H., 2010. The polar ocean and glacial cycles in atmospheric $\mathrm{CO}_{2}$ concentration. Nature 466, 47-55.

Smith, J.A., Vance, D., Kemp, R.A., Archer, C., Toms, P., King, M., Zarate, M., 2003. Isotopic constraints on the source of Argentinian loess - with implications for atmospheric circulation and the provenance of Antarctic dust during recent glacial maxima. Earth Planet. Sci. Lett. 212 (1-2), 181-196.

Smith, J.A., Hillenbrand, C.D., Pudsey, C.J., Allen, C.S., Graham, G.C., 2010. The presence of polynyas in the Weddell Sea during the Last Glacial period with implications for the reconstruction of sea-ice limits and ice sheet history. Earth Planet. Sci. Lett. 296, 287-298.

Sugden, D.E., McCulloch, R.D., Bory, A.J.-M., Hein, A.S., 2009. Influence of Patagonian glaciers on Antarctic dust deposition during the last glacial period. Nat. Geosci.. doi:10.1038/NGEO1474

Tanaka, et al., 2000. JNdi01: a neodymium isotopic reference in consistency with Lajolla neodymium. Chem. Geology. 168, 279-281.

Taylor, S.R., McLennan, S.M., 1985. The Continental Crust: Its Composition and Evolution. Blackwell, Oxford.

Teitler, L., Warnke, D.A., Venz, K.A., Hodell, D.A., Becquey, S., Gersonde, R., Teitler, W., 2010. Determination of Antarctic Ice Sheet stability over the last 500 ka through a study of iceberg-rafted debris. Paleoceanography 25. doi:10.1029/2008PA001691.

Vernaleken, J., 1999. Sedimentologische Untersuchungen spaetquartaerer glazialmariner Sedimente vom antarktischen Kontinentalhang vor Kapp Norvegia. Diploma
Thesis. Institute of Geology and Mineralogy, University of Cologne, and Alfred Wegener Institute for Polar and Marine Research, Bremerhaven/Bremen University, pp. 84.

Walder, A.J., Furuta, N., 1993. High-precision lead-isotope ratio measurement by inductively coupled plasma multiple collector mass-spectrometry. Anal. Sci. 9 (5), 675-680.

Walter, H.J., Hegner, E., Diekmann, B., Kuhn, G., Rugters Van Der Loeff, M.M., 2000. Provenance and transport of terrigenous sediment in the South Atlantic Ocean and their relations to glacial and interglacial cycles: $\mathrm{Nd}$ and $\mathrm{Sr}$ isotopic evidence. Geochim. Cosmochim. Acta 64, 3813-3827.

Wareham, C.D., Pankhurst, R.J., Thomas, R.J., Storey, B.C., Grantham, G.H., Jacobs, J., Eglington, B.M., 1998. Pb, Nd and Sr isotope mapping of Grenville-age crustal provinces in Rodinia-age crustal provinces in Rodinia. J. Geol. 106, 647-659.

Watson, A.J., Garabato, A.C.N., 2006. The role of Southern Ocean mixing and upwelling in glacial-interglacial atmospheric CO2 change. Tellus B 58, 73-87.

Winckler, G., Anderson, R.F., Fleisher, M.Q., McGee, D., Mahowald, N., 2008. Covariant glacial-interglacial dust fluxes in the equatorial Pacific and Antarctica. Science 320 (5872), 93-96. doi:10.1126/science.115059.

Yu, E.-F., Francois, R., Bacon, M.P., Fleer, A.P., 2001. Fluxes of 230Th and 231Pa to the deep sea: implications for the interpretation of excess $230 \mathrm{Th}$ and $231 \mathrm{~Pa} / 230 \mathrm{Th}$ profiles in sediments. Earth Planet. Sci. Lett. 191, 219-230. 